\title{
FRAY JUAN RIZI EN ITALIA *
}

\author{
POR \\ SALVADOR SALORT PONS \\ Becario de la Academia de España en Roma
}

\begin{abstract}
Since Tormo, Gusi and Lafuente wrote fray Juan Rizi's monograph in 1930, and Angulo \& Pérez Sánchez revised years later this study in their book Pintura madrileña del segundo tercio del siglo XVII, very little has been published about the life and work of the Benedictine painter. Furthermore, the Italian journey of Rizi, that involved the last 20 years of his life, has always been an enigma, resolved only in certain aspects, thanks to few news supplied by his biographers and the manuscripts the monk wrote during his staying in the Montecassino abbey. Our recent discovery of 8 new canvases painted by Rizi to decorate the Saints Cosme and Damian's chapel in the main church of Trevi nel Lazio (Frosinone, Italy), as well as the location of several new drawings in the Montecassino and Vatican libraries, will allow us to study his activity as painter in Italy and also to profile, with more accuracy, the history of the last years of his life.
\end{abstract}

El viaje a Italia ha sido considerado, desde el Renacimiento, como un paso necesario en el aprendizaje de un joven artista. Durante el siglo XVII, numerosos pintores flamencos, alemanes, franceses y holandeses visitaron las ciudades italianas más importantes, principalmente Roma, siquiera con dos claros propósitos, imprescindibles para su formación artística: el primero tenía por objeto el estudio de las obras de los maestros del pasado, tanto de la Antigüedad Clásica como del Renacimiento. El segundo; venía dado por el deseo de conocimiento, experimentación y participación en las nuevas corrientes estéticas que, en aquellos momentos, se desarrollaban en Italia, fundamentalmente en Roma, con el fin de «ponerse al día» en lo que a doctrina artística se refería.

Los maestros españoles del siglo XVII también eran conscientes de la importancia instructiva de la jornada italiana, sin embargo pocos de ellos, por diversas razones, vieron satisfecho su deseo. En este sentido, hay que señalar que, por lo que respecta a los grandes maestros de nuestro Siglo de Oro, solamente José Ribera pasó a Italia muy joven, estableciéndose en Nápoles, luego lo hizo Diego Velázquez que realizó, al menos, dos viajes y, finalmente, Fray Juan Rizi, quien se desplazó a Roma por cuestiones teológicas, en 1662, para ulteriormente, ingresar en el monasterio de Montecassino donde murió en $1681^{1}$.

\footnotetext{
" Quisiera expresar mi agradecimiento a D. Felipe V. Garín Llombart quien, desde la Academia de España en Roma, ha facilitado y respaldado, en todo momento, el desarrollo de mi trabajo investigador en Italia, así como a D. Alfonso E. Pérez Sánchez, D. ${ }^{a}$ Marcella Picca, D. Salvador Salort Pérez, Don Lucio, párroco de la Colegiata de S. María Assunta y Don Romano, monje benedictino de Subiaco, por su generosa ayuda y contribución en la consecución de los fines del presente estudio.

1 Asimismo, otros pintores españoles, quizá de desigual fama pero no por ello de menor interés para la historia de nuestra pintura, anduvieron por tierras italianas a lo largo del «seiscientos». De estos, merece la pena recordar a P. Orrente, J. Roelas, L. Tristán, P. Núñez, J. Martínez, F. Herrera «el Mozo», J.B. Mazo, V. Giner - fundador en 1680 de una Academia de Españoles en Roma-, entre otros.
} 
Sobre la etapa italiana de este último pintor - Ca. 20 años - se tenían, hasta la fecha, escasas noticias, suministradas, fundamentalmente, por sus biógrafos y los manuscritos que el propio benedictino escribió en Montecassino. Nuestro reciente descubrimiento de ocho nuevos lienzos pintados por Rizi en Italia, para la decoración de la capilla de San Cosme y San Damián de la Iglesia de Santa María Assunta de Trevi nel Lazio, así como el hallazgo de unos 20 dibujos inéditos en las bibliotecas Vaticana y de la Abadía de Montecassino, nos van a permitir, en las siguientes páginas, estudiar, en alguna medida, la actividad pictórica de fray Juan en Italia y establecer, con mayor claridad, la historia de los últimos años de su vida.

Como es bien sabido, fray Juan Andrés Rizi de Guevara ${ }^{2}$ nació en Madrid, en 1600, de Gabriela de Guevara ${ }^{3}$ y de Antonio Ricci de Ancona, pintor boloñés que vino como ayudante de Federico Zuccaro para decorar el Monasterio del Escorial. Sobre su infancia, formación artística y primeras realizaciones pictóricas tenemos muy pocos datos. Sabemos, gracias a sus propias declaraciones que, con tan sólo 16 años, escribió un tratado sobre la Inmaculada Concepción de la Virgen dedicado al papa Paulo V, circunstancia que testimonia una honda inquietud religiosa desde la adolescencia ${ }^{4}$. Palomino nos refiere que su educación como pintor se debe a las enseñanzas de Mayno ${ }^{5}$, sin embargo el análisis de las obras de Rizi no pone de manifiesto algún posible paralelismo, ni formal ni estilístico, con los lienzos del dominico. En este sentido, no es difícil intuir que el pintor recibiera sus primeras lecciones de su propio padre.

En 1628 profesó como monje benedictino del monasterio de Montserrat, en cuya iglesia decoró, entre 1637-41, las capillas del Santísimo y de San Bernardo (1637-41), ambas destruidas, posteriormente, durante la invasión francesa. Fray Juan debió abandonar Montserrat hacia 1640, pues no figura en la lista de los religiosos y escolares castellanos trasladados a Madrid, desde el monasterio, en 1641, a causa de la revuelta catalana ${ }^{6}$. Seguramente, en ese mismo año, viajó desde Salamanca —donde, anteriormente, había estudiado teología- a la Corte con el objetivo de ser maestro del Príncipe Baltasar Carlos y en donde, por las razones que él mismo relata, permanecerá poco tiempo ${ }^{7}$.

2 Por lo que respecta a la ortografía de su apellido Ricci o Rizi, tenemos que decir que fray Juan parece conservar, en sus manuscritos, las dos ces de su origen italiano. Y aunque Tormo y el padre Gusi respetan la escritura del benedictino, nosotros preferimos mantener la zeta tal y como hicieron su propio hermano Francisco, Palomino, Ponz, Jovellanos, Beruete, Mayer y, más tarde, Angulo y Pérez Sánchez.

3 La bibliografía existente sobre el pintor fray Juan Rizi es, fundamentalmente, la que sigue: Tormo, E., Gusi, C. y Lafuente, E., La vida y la obra de Fray Juan Ricci, Madrid 1930, 2 vol.; Angulo, D. y Pérez Sánchez, A., Pintura madrileña del segundo tercio del siglo XVII, Madrid 1983, pp. 268-312; Ramírez, J. A., «Guarino Guarini, Fray Juan Ricci y el orden Salomónico entero», Goya, 1980, n.ำ160, pp. 202-211.

4 «Siendo de diez y seys años (Santísimo Padre) escrivi un libro de la ynamculada concecion de la virgen el qual remiti a la santidad de Paulo V para que veniendo a la luz, lo manifestase a la Yglesia y no es maravilla si hablase como muchacho.» Copia de la carta dirigida al papa Alejandro VII, folio 17 del Manuscrito.$^{\circ} 590$ de la biblioteca de Montecassino.

5 Palomino, A. El Museo Pictórico y la Escala Óptica. El Parnaso Español Pintoresco Laureado. Madrid, 1715-1724. Edición Aguilar, 1988. Vol. III, p. 335.

6 Analecta Montserratensia, vol. IV.

Manuscrito n. 590 de la Biblioteca de Montecassino. Copia de una carta dirigida a la Duquesa de Béjar, fechada en Roma en 1663. Folios 4 y 5. «...pues haviendome echo yr de Salamanca a Madrid para serlo (maestro del príncipe), el Conde Duque, el Protonotario de Aragón D. Jeronimo de Villanueva, el Sr. Obispo de Badajoz D. Joseph de la Cerda gloria de mi Cogulla, y que lo es oy de Urgel, D. Joan Manuel de Espinosa, por impedirle a su S. ${ }^{\text {a }}$ la reelección que su Magestad hizo en su S..$^{\text {a }}$ de Abbad reelecto del Nuevo Monserrate de Madrid, en la expulsion de los Monges Castellanos del Monasterio Real de N.. S. ${ }^{\mathrm{a}}$ de Montserrate de Cataluña, me amenazaron tan poderosas personas como me movio de mi centro, con que perdiera ser maestro de Su Alteza. Y respondi que primero eran las constituciones de mi religión, que no permiten reelecciones, fuera de que a mi me hacian mayor honrra en no hacerme maestro de niños, aunque sean tan grandes, y asi contradixe con mas esfuerzo el nombramiento regio, y el señor nuncio de España conociendo mi justicia, firmo dicho nombramiento 
Desde 1642 hasta 1662 su actividad en la orden fue intensa. Viajó por distintos monasterios castellanos (Silos, San Juan de Burgos, San Millán de la Cogolla, Medina del Campo...), donde alcanzó dignidades eclesiásticas y dejó importantes ciclos pictóricos y algunas realizaciones arquitectónicas ${ }^{8}$. A todas estas series monásticas del «Zurbarán castellano», como acertadamente le llamó Justi, se tienen que añadir sus obras de retratista, como el «Tiburcio Redín» o el «Fray Alonso de San Vítores», que son claro reflejo de la admiración del benedictino por Velázquez. Antes de su paso a Italia y como se desprende de sus escritos ${ }^{9}$, fue protegido por los Duques de Béjar, para quienes pintó diversas obras ${ }^{10}$, siendo, a su vez, maestro de la propia duquesa, D. ․ Teresa de Sarmiento de la Cerda.

El viaje a Italia de fray Juan tuvo lugar durante el mes de octubre de 1662, ya que el 1 de noviembre de aquel año, llegó a Roma ${ }^{11}$. Las razones del mismo, como se sabe, tienen un componente principalmente religioso: el de aclarar el misterio de la Inmaculada Concepción de la Virgen ${ }^{12}$. Esta «misión teológica» no parece que, por las noticias que da Palomino, impidiera la actividad artística del pintor: "pasó a Roma, donde se incorporó en aquella Sagrada Congregación de Monte Casino, y donde hizo muchas pinturas, que fueron en Roma celebradas. Y habiendo visto el Papa dos apostolados de su mano, los admiró mucho, y gustó de conocerle, y le hizo muchas honras...» ${ }^{13}$. Aparte de la cita de Palomino, de su estancia y actividades en Roma, antes de pasar a Montecassino, sabemos que realizó el proyecto de renovación de la plaza de la Rotonda, en donde se incluía una nivelación del terreno y el bosquejo de una fuente central en la que, sobre un pedestal representando seis montañas superpuestas (motivo del escudo de la familia Chigi), se apoyaba una columna helicoidal, sobre la que descansaba una escultura de la Inmaculada Concepción. Además, hay que señalar que, probablemente durante su estancia romana, también preparara un proyecto de reforma

condicionalmente con que no perjudicare dichas constituciones con estas palabras. Dummodo non vulnerentur statuta Religionis. Y furiosos de ver que les havia frustrado nombramiento de un Rey, sacaron otro, ya que no de Abbad, de Presidente, y oy le tienen, y a mi de Madrid a Santo Domingo de Sylos, donde me vi gozoso fuera de Palacio».

8 Para el estudio en profundidad y discusión de toda su obra pictórica conocida en España, véase el citado libro: Angulo, Pérez Sánchez, Obra cit. Madrid 1983, pp. 268-312 y láminas 253-308. Como arquitecto en España, proyectó la fachada del Convento de Medina del Campo y, en 1645, construyó una capilla octogonal para el Monasterio de Santo Domingo de Silos. Véase nota n.․․ 3 .

9 «Excelentísima Señora, el haver venido a esta Corte Romana, tan lexos de V.Ex $x^{\mathrm{a}}$, no me hace olvidar de mis obligaciones y de las muchas, y repetidas mercedes de excelentisima sangre que estoy reciviendo, sobre las recividas de $\mathrm{VEx}^{\mathrm{a}}$ y para aportar de mi mucho mas, si mas puede ser, a la ociosidad, que siempre aborreci, determiné dedicar a V.Ex $x^{\mathbf{a}}$, segundo ..... trabajo que para mi es alivio y gloria el servirla a VEx $x^{\mathbf{a}}$ siendo para mi lo mas penoso, considerar si la ofendo, quanto y mas el ofenderla; mas fiando de su virtud y nobleza, prosigo en servirla para que no este ociosa la dignidad mayor de maestro Mayor del Exmº señor Duque de Béjar hijo legitimo de $V_{E x} x^{a}$ en todo y señor mio...» Véase nota $n^{0} 7$. Esta declaración de maestro del Duque no concuerda con la relación de Palomino quien afirma que Rizi era maestro de la Duquesa. Sobre ello, es posible pensar que quizá el libro de Pintura Sabia, escrito por encargo de los Béjar, tenía, como uno de sus objetivos, el de instruir al joven duque. A este respecto, el padre Gusi apunta que el tratado pudo haberlo escrito en Madrid entre los años de 1659 al 62. Tormo, Gusi, Lafuente, Obra cit. Madrid 1930, vol. I, p. 40.

${ }^{10}$ A pesar de que nuestra tesis doctoral se ocupa del coleccionismo privado de pinturas en el Madrid de los siglos XVII y XVIII, no hemos conseguido encontrar, entre los abundantísimos inventarios que manejamos, el de la Duquesa de Béjar que, en este caso, hubiera sido de gran interés.

${ }_{11}$ El propio benedictino así lo indica en una cronología incluida en los folios 368-371 del manuscrito $n .{ }^{\circ} 590$ de la biblioteca de Montecassino: «1662, $1 .{ }^{\circ}$ de Noviembre vine a Roma para ver si podía hacer definir el Misterio de la Inmaculada Concepción haviendo escrito otro de este Misterio cuyo argumento es Ymagen de Dios y de sus obras. Y otro Inmaculae Conceptionis selurio», (folios 370-1).

12 Tormo, Gusi, Lafuente, Obra cit. Madrid 1930, vol. I, folio 48.

13 Palomino, A., Obra cit. Madrid, 1715-1724. Edición Aguilar, 1988. Vol. III, p. 336. 
del baldaquino, levantado por Bernini en San Pedro, de la valla del coro y del presbiterio de la basílica. Todo ello, como se puede ver en sus dibujos ${ }^{14}$, venía modificado a través de un nuevo orden arquitectónico por él inventado: el orden Salomónico Entero o Completo ${ }^{15}$.

La llegada de fray Juan al cenobio de Montecassino se ha fechado, por el padre Gusi, aproximadamente en el año 1670. Sin embargo, como veremos a continuación, parece que Rizi ya estaba en el citado monasterio, en $1666^{16}$. La vida de fray Juan en Montecassino, tal y como la describen dos de los cronistas de la abadía, D. Mariano Armellini y D. Erasmo Gattula ${ }^{17}$, fue virtuosa y de sobriedad ejemplar. Hacía largos ayunos, no vestía el atuendo regular de lana sino otro más áspero, era asiduo a la horas canónicas, dormía poco y con las ventanas siempre abiertas empero las condiciones atmosféricas, celebraba misa de madrugada... A todo ello, se añade su actividad pictórica e intelectual por la que se hizo famoso entre sus cofrades. A este respecto, decoró, con sus pinturas, la capilla del Santísimo Sacramento que se encontraba en el flanco izquierdo del coro de la iglesia de la abadía y, además de los tratados religioso y pictórico ya citados, también escribió varios textos sobre las edades del Mundo, teología escolástica y moral, comentarios a la Sagrada Biblia, astronomía, dialéctica, retórica, geometría, medicina, entre otros ${ }^{18}$. En ellos, utilizaba principalmente, como instrumento de expresión el latín, aunque, en algunos casos, incluía al final o al principio de sus escritos un vocabulario de los conceptos principales en varias lenguas: griego, hebreo, alemán, francés e italiano. Tuvo el grado de maestro, equivalente al de doctor universitario, Alejandro VII le nombró Predicador General en Italia ${ }^{19}$ en 1663, más tarde, como narra Palomino, se le concedió un obispado que parece ser no debió ocupar ${ }^{20} \mathrm{y}$, en general, fue reconocido, como manifiesta Armellini, por sus saberes: Hic tam Scholasticis scientiis, quam liberalibus artibus eruditus, \& Theologum, \& concionatorem, \& Pictorem, \& Architectum, prout ingenium, aut occasiotulit, aequaliter se praebuit ${ }^{21}$.

${ }_{14}$ Hemos encontrado las trazas originales de estos proyectos en el fondo de manuscritos de la Biblioteca Apostólica Vaticana (Mss Chigiani E-VII-257), que, probablemente, fray Juan entregó al papa Alejandro VII. Asimismo, como publicaron Tormo, Gusi y Lafuente, dentro del manuscrito n. 590 de la biblioteca de Montecassino se incluyen los dibujos de los citados proyectos, aunque, estos últimos, son de menor tamaño que los de la Biblioteca Vaticana. Para un estudio de los mismos, Tormo, Gusi, Lafuente, Obra cit. Madrid 1930, vol. I, láminas: CLXVIII (Plaza de la Rotonda), CLXVI y CLXVII (Baldaquino y reja del altar papal en San Pedro del Vaticano). Como ha demostrado el padre Gusi, la nivelación del terreno de la plaza de la Rotonda se llevó a cabo. Tormo, Gusi, Lafuente, Obra cit. Madrid 1930, vol. I, folios 58 y 65 n.ํํ. 59.

${ }_{15}$ Véase a este respecto, Ramírez, J. A., «Obra cit». Goya, 1980, n. 160, pp. 202-211.

${ }_{16}$ En 1665, todavía está en Roma pues el 6 de enero de aquel año, como él mismo declara, avista un cometa desde la Ciudad Eterna. Esta noticia se puede leer en el Manuscrito ${ }^{\circ}{ }^{\circ} 590$ de la biblioteca de Montecassino, folio 374, en donde estudia y dibuja el citado cometa.

17 Armellini, M., Biblioteca Benedictio-Cassinensis sive Scriptorum Cassinensis Congregationis. Auctore M.A... Assisii Anno MDCCXXXII, pars altera, folio 18. Gattula, E. Historia Abbatiae Cassinensis. Venetiis, MDCCXXXIII, pars secunda, folio 760.

${ }_{18}$ En el índice de manuscritos que posee la biblioteca de Montecassino, se relacionan los siguientes textos de fray Juan: Ricci / Johanis Andrea. Commentaria in S. Scriptura libros pluros (Codd. 469, 470, 471, en n..$^{9}$ romanos); Executiones Morales seu Theologia Scholastica, Aureola Aurea (Cod. 472, en n. ${ }^{\circ}$ romanos); Tractatus Teologici (Codd. 537, lib. X); Opera Philosophica (Cod. 544); Commentaria in Genesis, Alia quedam opera (Cod. 545); Epitome Architecture, Index Pontificium Regum et imperatorum, Oracoli Turcheschi in Italia, De Sacrificio Messe, et vestibus sacerdotalibus (Cod. 590).

19 «Su Santidad me hizo Predicador General» y en el margen escribe: «1663, oct 27. Recibi el breve víspera de todos los Santos el más honorífico que sea dado como consta del mismo» Manuscrito 590, folio 371.

20 Palomino, A., Obra cit. Madrid, 1715-1724. Edición Aguilar, 1988. Vol. III, p. 336. No se tiene constancia de que llegara a tomar posesión de este obispado, ya que no figura en los catálogos de los obispos casinenses. Angulo, Pérez Sánchez, Obra cit. Madrid 1983, p. 271.

${ }^{21}$ Véase nota n. ${ }^{9} 17$. 
Gracias a nuestras investigaciones, podemos afirmar que fray Juan no pasó todo su tiempo en el cenobio casinés y, en base a las mismas, nos parece posible pensar que de igual modo que en España el benedictino viajó bastante, llevando a cabo diversas actividades artísticas por Castilla la Vieja, Navarra y Cataluña, también pudo haberse desplazado y haber trabajado, por las poblaciones de las regiones internas de Italia, cercanas a Roma y Montecassino. Tenemos noticia de que en 1666, se encuentra en la localidad de Trevi nel Lazio decorando, con sus pinturas, la capilla de San Cosme y San Damián de la colegiata de Santa María Assunta ${ }^{22}$. Posteriormente, en 1668 y 1669, se debió trasladar a la ciudad del Aquila, donde compuso y fechó, al menos, dos dibujos, a saber: un jeroglífico apoteósico dedicado a Carlos II con motivo de su cumpleaños (fig. 8) y, otro, del «paso del Mar Rojo» que ilustraba sus comentarios manuscritos al Éxodo (fig. 19) ${ }^{23}$.

Trevi nel Lazio es una pequeña población del alto valle del Aniene, situada en la actual provincia de Frosinone ${ }^{24}$. Dista aproximadamente unos 80 kilómetros de Montecassino e históricamente fue territorio de dominio, primero de la familia Gaetani y más tarde, papal. No conocemos cuáles fueron las razones que pudieron llevar a Rizi a pintar en la iglesia principal de Trevi, sin embargo es fácil intuir que su trabajo fuera un encargo favorecido por el abad de Montecassino, ya que Trevi estaba sujeta a la regulación del monasterio benedictino de Subiaco ${ }^{25}$ y éste, a su vez, tenía unas relaciones estrechísimas, desde 1514, con la abadía de Montecassino. A su vez, y siempre en relación con los móviles que pudieron empujar a Rizi a pintar en la citada colegiata, hay que apuntar que nuestras investigaciones en archivo, nos han permitido observar que algunas personas de apellido Ricci vivían en Trevi a mediados del siglo XVIII ${ }^{26}$. Esta circunstancia, por lo menos, podría dar pie a suponer que el maestro madrileño hubiera llegado a Trevi por cuestiones familiares y, una vez allí, haber pintado la mencionada capilla gracias a algún encargo local, hecho que por el momento no hemos podido comprobar.

En la «Insigne Chiesa Collegiata Parrocchiale di S. Maria Assunta» dice la tradición que fue enterrado el cuerpo de San Pedro ermitaño, patrón de Trevi nel Lazio. La iglesia fue consagrada en 1616, y en ella se construyó la capilla de los Santos Cosme y Damián (fig. 1), primera de la nave del Evangelio, donde, en la actualidad, se pueden ver los siguientes cuadros (de arriba hacia abajo y de izquierda a derecha): «Alegoría de la S. Trinidad», «Cristo y N. $\mathrm{S}$. sujetando el Cáliz con la Hostia y la paloma del Espíritu Santo», «N.. S. a con el Niño coronada por ángeles», «San José y San Juan Bautista», «S.C. Borromeo», «S. José con el Niño», «S. Pedro», «San Pablo», «S. Antonio de Padua», «S. Francisco».

La descripción más antigua que hemos encontrado de la capilla está en la crónica, Memorie del Lazio, de Domenico Pierantoni, quien refiere lo siguiente: la «Capella con altare dei Santi Cosmo e

${ }^{22}$ Esta información la hemos deducido de una pequeña guía que se regala en la citada iglesia de Trevi. En ella, se declara que 8 lienzos de la capilla de San Cosme y San Damián fueron pintados por un monje casinés español. Valle, M della, Guida turística di Trevi nel Lazio, 1994, p. 16.

23 Este jeroglífico que lo cita el padre Gusi, no fue, sin embargo, reproducido en el libro de Tormo, Gusi y Lafuente. En él aparece una inscripción de la que se deduce, como vamos a estudiar más adelante, que fray Juan lo compuso en la ciudad del Aquila, en 1668.

${ }^{24}$ Sobre Trevi nel Lazio existen varias publicaciones: Zinani, D., Trevi nel Lazio, nella storia, nell'arte, nelle tradizioni, Roma 1972; Caraffa, F. Trevi nel Lazio, delle origine alla fine del secolo XIX, Roma 1973, 2 vol. A su vez, existe el manuscrito (siglos XVII y XVIII) del erudito Domenico Antonio Pierantoni (1646-1727), Memorie del Lazio, en cuyo volumen 25 se incluye la descripción de la ciudad de Trevi. Este libro se encuentra en el archivo del ayuntamiento de Trevi nel Lazio.

25 A Trevi nel Lazio también se la conoce como Trevi di Subiaco.

26 Archivio di Stato (Roma), S. Congregazione del Buon Governo, serie II, buste 5198 al 5207, serie III busta 84. Entre esta documentación encontramos diversas personas con el apellido Ricci: Francesco Ricci, Carlo Ricci, Andrea Ricci. Desconocemos el número de habitantes de Trevi en el siglo XVII, para poder evaluar este dato. Hoy en día, tiene ca. 800. 
Damiano, la compro dalla communitá Pietro Paolo Marij, Dottor in legge, anno 1661..... decorata con un nobil quadro opera del cavalier Manenti senese, anno 1662 con la imagine ancora di san Rocco protetore contro la peste» ${ }^{27}$. Como vemos, Pierantoni, en su manuscrito, describe el cuadro que debía decorar el altar dedicado a «San Cosme y San Damián», el cual lo atribuye a un pintor llamado Manenti y, sin embargo, nada menciona de los cuadros que, hoy en día, se pueden observar en la capilla ${ }^{28}$. A su vez y tratando de buscar noticias sobre la misma, hemos consultado otras guías y estudios realizados sobre la colegiata de Trevi y, en todos ellos, se repiten sistemáticamente las palabras de Pierantoni, excepto en uno. Nos referimos a la guía del ingeniero Mario della Valle ${ }^{29}$, quien al referirse, en su descripción de la iglesia, a la capilla en cuestión escribe lo siguiente: «la cappella della SS. Trinitá e S. Rocco, poi SS. Cosma e Damiano (dal 1527 della famiglia Mari, demolito l'altare nel 1967, quadro del 1662 del Manenti con SS Trinitá e tre Santi; ai lati e sopra, otto pannelli dipinti da monaco cassinese spagnolo 1666)».

Desconocemos cuál es la fuente de información del ingeniero della Valle ${ }^{30}$, ahora bien, los ocho paneles que atribuye a un «monaco cassinese spagnolo», son, como seguidamente demostraremos, obra indudable de fray Juan Rizi. En relación con la procedencia de la noticia que facilita della Valle, sospechamos que debe ser de origen archivístico ya que, la seguridad con la que nos da la fecha, 1666, y la afirmación tajante de que es un pintor del cenobio casinés y español, así lo hacen pensar. Por consiguiente, si damos autenticidad al dato del ingeniero, éste nos está indicando que fray Juan ya estaba bajo la disciplina de Montecassino en 1666, fecha en la que pintó los ocho lienzos y que, por lo tanto, ya había abandonado Roma.

Antes de pasar al análisis de la obras de Rizi, debemos explicar algunos aspectos sobre la capilla. Ésta fue demolida en 1967 por razones estructurales de la iglesia y, en su reconstrucción posterior, no se respetó la antigua fisonomía de la misma ${ }^{31}$. El lienzo central del altar que, en la actualidad, se puede ver: «N.a S. a con el Niño coronada por ángeles, San José y San Juan Bautista» se atribuye a Vincenzo Manenti ${ }^{32}$ y sustituye a otra obra, de mayor calidad y, en la actualidad, en paradero desconocido, que representa a la «Santísma Trinidad con los santos Roque, Damián y Cosme», cuyo autor no podemos precisar (solamente tenemos una fotografía de la misma), aunque podría estar en el entorno estilístico de Francesco Cozza o Jacinto Brandi ${ }^{33}$.

Los lienzos pintados por fray Juan son, por lo tanto, los ocho restantes (de arriba hacia abajo y de izquierda a derecha): «Alegoría de la S. Trinidad», «Cristo y N.a S. a sujetando el Cáliz con la Hostia y la paloma del Espíritu Santo», «S. Carlos Borromeo», «S. José con el Niño», «S. Pedro», «S. Pablo», «S. Antonio de Padua», «S. Francisco» ${ }^{34}$. En todos ellos se ad-

${ }^{27}$ Pierantoni, D.A. Memorie del Lazio, Manuscrito de los siglos XVII y XVIII, vol. 25, folio 245. Véase nota.$\stackrel{\circ}{ } 24$.

${ }_{28}$ Pierantoni relaciona otros datos referentes a la capilla que hemos omitido, por ser de menor interés para nuestro estudio.

29 Véase nota n. ${ }^{\circ} 22$

30 En busca de la documentación referente al contrato de las pinturas, hemos revisado sin éxito, los siguientes archivos: el de la colegiata de Trevi, el del ayuntamiento de Trevi y el de Stato de Roma (Protocolos notariales).

31 Zinani, D., Obra cit., Roma 1972, p. 129.

32 Di Flavio, V. «Ascanio e Vincenzo Manenti, pittori sabini del XVII secolo», Lunario Romano, 1989, n.․ XIX, pp. $127-140$.

${ }_{33}$ En una fotografía general de la capilla, antes de su restauración, se puede observar este cuadro que, en la actualidad, no existe y que ha sido sustituido por el del citado pintor Manenti.

${ }^{34}$ El cuadro de San Francisco estaba anteriormente colocado en el lugar del de S. Carlos Borromeo y viceversa. Esta información la conocemos gracias a que hemos podido observar dos fotografías tomadas antes y después de una restauración realizada ca. 1970. 
vierte, al igual que en su obra dejada en España, un decidido naturalismo, una utilización de la luz dirigida y contrastada en claros y oscuros fuertes, una composición sobria que potencia lo esencial y huye de lo accesorio, vigorizando, a su vez, la severa monumentalidad de sus modelos. La ejecución de las obras es áspera, desabrida, angulosa y nerviosa, con poca materia pictórica, proyectando una sensación de inacabado, de pintura hecha rápidamente ${ }^{35}$. A pesar del ennegrecido estado en que se conservan los lienzos, se puede observar un predominio de los tonos cálidos de colores rojos, marrones, ocres y azules en los mantos. En éstos, se advierten valientes toques de blanco, que se extienden vertical y horizontalmente, dando volumen a las figuras y una suntuosidad casi veneciana a algunas telas. Las carnaciones varían desde el tostado de algunos rostros al blanco de Jesús Niño y, en muchos de ellos, todavía se advierten los labios colorados y el sonrosado de las mejillas, tan habituales en los modelos del pintor.

En la parte superior de la capilla y adaptándose al intradós del arco que la enmarca, se sitúa el óleo sobre lienzo ${ }^{36}$ de la «alegoría de la Santísima Trinidad» (fig. 2). Ésta se representa con tres figuras adolescentes de medio cuerpo, vestidas con hábitos azules y rojos, que sujetan un crucifijo clavado en una roca, todo ello, sobre fondo negro. El lamentable estado de conservación y la altura en la que está situado el lienzo no permiten un estudio en profundidad del mismo. Solamente podemos resaltar que esta singular composición se repite varias veces, con diversas variantes, en los dibujos que ilustran dos de los manuscritos del benedictino en Montecassino ${ }^{37}$.

Inmediatamente debajo de la «alegoría de la Santísima Trinidad» y cubierto por el arco que limita la capilla en su zona alta, se emplaza el lienzo de «Cristo y N. ‥ S. ${ }^{a}$ sujetando el Cáliz con la Hostia y la paloma del Espíritu Santo» (fig. 3). De nuevo, en este caso, fray Juan vuelve hacer uso de una composición que guarda un estrecho parecido con uno de sus dibujos incluido en los volúmenes casinenses ${ }^{38}$. En este lienzo, se hace patente la sobriedad y claridad compositiva de Rizi, que elimina lo accesorio y presenta, de forma explícita, el mensaje religioso de redención a través de la muerte y la resurrección de Cristo, con el papel fundamental de la Virgen, en el hecho de la salvación de la humanidad. Esta sobriedad compositiva es el marco perfecto para unos modelos monumentales de formas rotundas, que reciben una luz desigualmente dirigida a puntos concretos, combinándose, de este modo, las zonas fuertemente iluminadas con otras en penumbra. La Virgen es una niña y el Cristo un hombre maduro, delgado, con barba y cabellos largos. Sus rostros son dos modelos del natural que ya había utilizado en otras composiciones como, por ejemplo, en algunos lienzos de San Millán de la Cogolla ${ }^{39}$. Entre los dos sujetan el Cáliz ${ }^{40}$, sobre el que flota la Hostia y por encima, viniendo de un rompimiento celeste, la paloma del Espíritu Santo que, con las alas abiertas y mostrando las patas, desciende no sólo en la escena sino también, sobre el espectador.

35 A pesar de haber sido restaurados por la Sovrintendenza, los cuadros se conservan en un alarmante mal estado. Ignoramos si la ausencia de cuerpo pictórico se debe a su mala conservación o si por el contrario, en su origen, el pintor utilizó poca materia cromática. Hay que recordar, la sorpresa que produjo la reciente restauración de los cuadros del trascoro de la catedral de Burgos, por lo entintados que aparecieron, circunstancia novedosa en la obra conocida de Rizi.

36 Todos los cuadros están hechos con la técnica del óleo sobre lienzo.

37 Véanse las láminas: CXLIX (Ilustración al Génesis, Ms 469.), CLI (Ilustración al tratado teológico, Ms 537). Tormo, Gusi, Lafuente, Obra cit. Madrid 1930, vol. I.

${ }_{38}$ Véase la lámina n. ${ }^{\circ}$ CLVI (Ilustración del tratado Teológico, Ms 537). Tormo, Gusi, Lafuente, Obra cit. Madrid 1930, vol. I. Este dibujo es el reverso del folio 15. En el anverso se repite.

39 «San Benito y San Miguel Florentino reciben el rosario».

40 Rizi utiliza también este modelo de Cáliz, que nada tiene que ver con el que se conserva como reliquia de la última cena en la Catedral de Valencia, en sus dibujos de los manuscritos de Montecassino. Véase, más adelante, el dibujo que se incluye en el presente escrito. 
Ambas figuras van vestidas con amplios y pesados ropajes que, en el caso de la Virgen, resultan muy aparatosos y desproporcionados. Éstos se conforman con telas multiplegadas y angulosas que parecen de «cartón-piedra» y que apenas permiten adivinar la anatomía de los cuerpos debajo de ellas. Por lo que respecta al cromatismo, prevalecen, en la composición, los tonos cálidos de rojo y azul. Son colores argénteos sobre los que se aplican numerosos golpes de blanco que producen una grata sensación de brillos, de riqueza y suntuosidad casi veneciana, sobre todo, en el manto azul de la Virgen ${ }^{41}$. Finalmente, se advierte, al examinar detenidamente el lienzo, un buen dibujo en los primeros planos y una factura abreviada en el paisaje de fondo.

Debajo del cuadro «Cristo y N. ‥ S. sujetando el Cáliz....», se sitúa la tela principal del altar, «N. S. ${ }^{\text {a }}$ con el Niño coronada por ángeles, San José y San Juan Bautista», ya citada y ajena a Rizi. Esta pintura, en sus dos laterales, queda flanqueada por seis lienzos oblongos (154 x $42 \mathrm{~cm}$.), dispuestos en dos grupos de tres a cada lado, que representan seis santos de pie (de izquierda a derecha): «San Carlos Borromeo», «San José con el Niño», «San Pedro», «San Pablo», «San Antonio de Padua», «San Francisco». Todos ellos, como ya hemos afirmado, obras seguras del pintor monje.
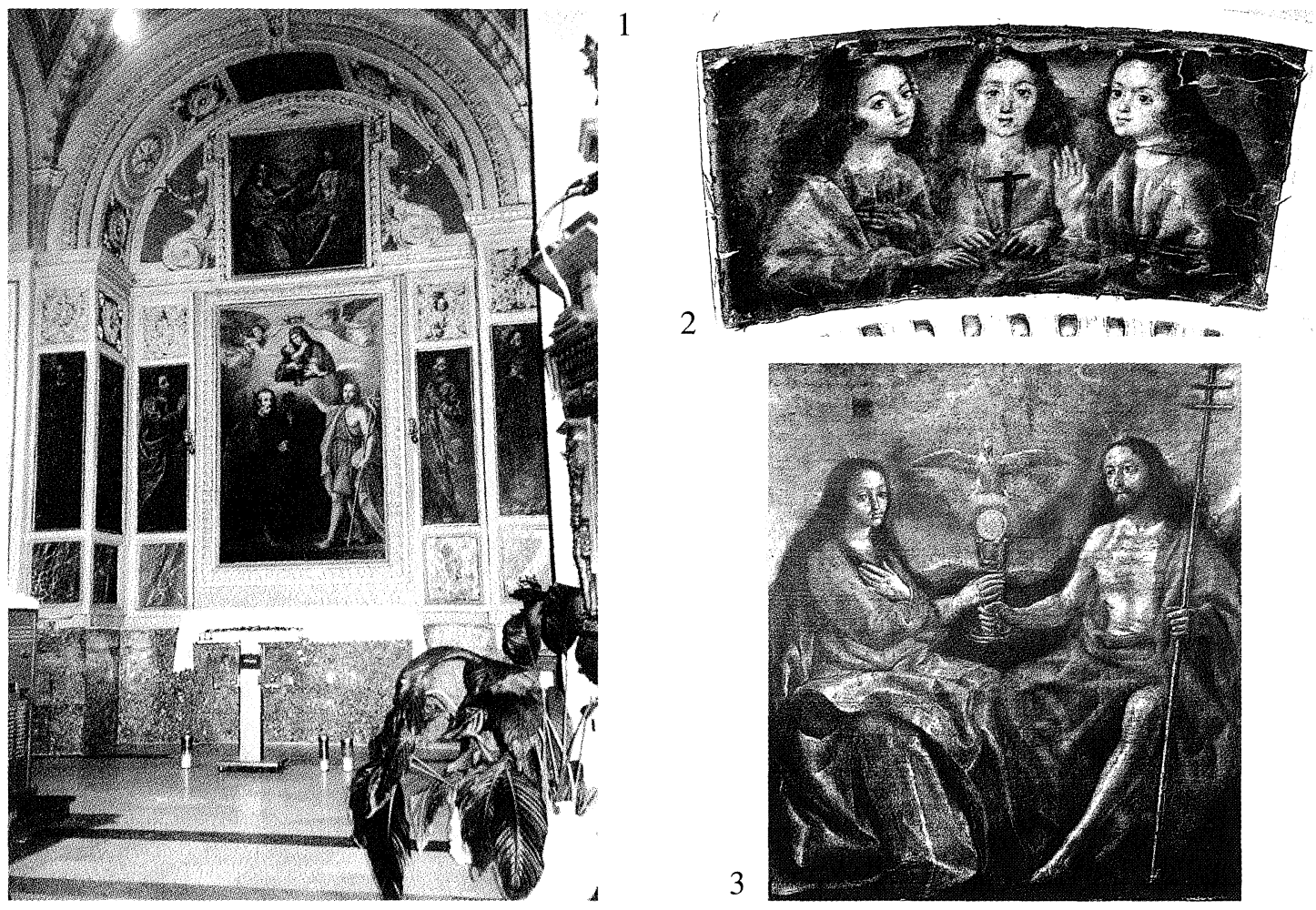

Figura 1. Capilla de los santos Cosme y Damián. Colegiata de Santa Maria Assunta. Trevi nel Lazio (Frosinone. Italia). Figura 2. Alegoría de la Santísima Trinidad. Intradós del arco de la capilla de los santos Cosme y Damián. Colegiata de Santa Maria Assunta. Trevi nel Lazio (Frosinone. Italia). Óleo sobre lienzo.

Figura 3. Cristo y $N .{ }^{\underline{a}} S .^{\underline{a}}$ sujetando el Cáliz con la Hostia y el Espíritu Santo. Capilla de los santos Cosme y Damián, Colegiata de Santa Maria Assunta. Trevi nel Lazio (Frosinone. Italia). Óleo sobre lienzo, 120 x $120 \mathrm{~cm}$.

${ }^{41}$ Esta suntuosidad de las texturas de los tejidos está muy en relación, no solamente con algunos lienzos hechos en España, como la «Santa Victoria» de la Catedral de Burgos, sino también con las corrientes pictóricas que se desarrollaban, en aquellos momentos, en Roma: el llamado Neovenecianismo. 
$\mathrm{El}$ «San Carlos Borromeo» ${ }^{42}$ es un hombre de rostro individualizado, está vestido de cardenal, con hábito y bonete rojos, y sujeta, con las dos manos, un crucifijo sobre el que dirige la mirada. En la parte inferior del lienzo, se observa que el santo anda descalzo, como gesto de humildad, y que al lado de sus pies, de entre sus ropajes, surge una calavera que muestra al espectador su parte interior. Este tipo de naturaleza muerta, en la que, se intuyen magníficas calidades, ya la había utilizado Rizi en el trascoro de la catedral de Burgos ${ }^{43}$, es una clara alusión a la fatuidad de la vida y a la victoria de Cristo sobre la muerte. La figura del S. Carlos es monumental, recortándose en el cielo que, a la altura de su cabeza, se abre en un claro de luz, rematado por su aro de santidad. El cuerpo del santo se aprieta en los límites del marco sobrepasándolos, circunstancia que, sumada a un punto de vista bajo compositivo, nos lo proyecta hacia el espectador. El rojo cálido e intenso de sus vestimentas invade todo el lienzo y, de nuevo, golpes efectistas de blanco y de diferentes tonos rojos de menor intensidad dan cuerpo táctil a las formas, presentan los brillos del terciopelo de su hábito y las transparencias de la manteleta.

En el «San José con el Niño en brazos» (fig. 4), padre e hijo se miran mútuamente y, a su vez, el pequeño, en un ademán de ternura, acaricia la cara del padre terrenal ${ }^{44}$. Los rasgos faciales de Jesús Niño son los mismos a los que nos tiene acostumbrados fray Juan, y San José es un hombre con barba, cabello largo, piel tostada y va calzado con unas sandalias que dejan ver los pies. En el Niño se observan unas carnaciones más blancas que en el padre y, ambos, tienen los labios rojos y las mejillas coloradas. De nuevo, la figura de San José es rotunda y su monumentalidad se debe a que Rizi ha compuesto la escena con un punto de vista bajo, recortando la figura del santo en el cielo. En cuanto al cromatismo, prevalecen el ocre y el gris de las vestimentas de S. José, que causan un bello efecto plástico gracias a la angulosidad y caída pesada de sus plegados. Sobre éstos golpea la luz violentamente, combinando zonas muy iluminadas con otras oscuras, que dan relieve y volumen a las superficies y producen, en consecuencia, una sensación de realidad cercana.

Fray Juan representa a «San Pedro» (fig. 6) de medio perfil, sujetando las llaves y dirigiendo la mirada hacia el altar. En sus facciones, hermanas a las del «San Pedro» de San Millán de la Cogolla, descubrimos, de nuevo, los labios rojos y las mejillas sonrojadas con las que Rizi dota a muchos de sus modelos. De igual modo que en el cuadro de «San José», nos encontramos ante un figura corpórea, imponente y sólida. En sus vestimentas, de tonos ocre y plata, se vuelve a presentar el múltiple juego de aristas, picos y esquinas, que forman abundantes recodos en las telas, y que proporcionan a la hechura, la plasticidad característica de las obras del maestro. De esta composición, merece la pena resaltar el dramatismo con el que, el benedictino, consigue destacar la mano derecha del apóstol, del fondo oscuro del cuadro. La diestra de San Pedro se presenta con una hechura vibrante y alargada, donde la luz golpea bruscamente, proporcionando a la representación viveza y verdad.

$\mathrm{El}$ «San Pablo» (fig. 7) es, en nuestra opinión, la figura mejor ejecutada. En ella se observan de forma patente, las características estilísticas que hemos venido describiendo en las anteriores imágenes: fuerte corporeidad y presencia, plasticidad casi táctil en los ropajes, luz enfocada... Igualmente que en el «San Pedro», la topografía facial del santo se relaciona es-

${ }^{42}$ No estamos completamente seguros de que sea S. Carlos Borromeo. A nuestro favor está el hecho de que vaya vestido de cardenal y esté adorando la cruz. Sin embargo, sus rasgos faciales, que deberían mostrar una nariz más prominente, no se ajustan plenamente al tipo aguileño de su iconografía. De todos modos, hay que destacar que, dentro del repertorio de obra conocida del benedictino, es la primera vez que aparece este santo.

43 «Estigmatización de San Francisco».

${ }^{44}$ Dentro del repertorio de obra conocida del benedictino, es la primera vez que se descubre esta iconografía. El ademán de ternura entre el Santo y el Niño, es un gesto bastante habitual en la composiciones de Rizi que se puede observar, no solamente en los dibujos de Montecassino sino también, en el «San Antonio» del trascoro de la Catedral de Burgos. 
trechamente con la del «San Pablo» de San Millán de la Cogolla y, asimismo, tiene los pómulos sofocados y los labios encarnados. Su barba queda hecha con una factura suelta, dando sensación de inacabada, mientras que sus ojos vibran de forma especial, recordando, si cabe, el temblor lacrimal que el Greco imprimía a sus santos. Nuestro «San Pablo» sujeta la Sagrada Escritura con la mano derecha y con la izquierda un largo espadón, salpicado en su hoja de brillos metálicos, que cruza la composición de izquierda a derecha, suministrando a la figura una esbeltez especial, casi fusiforme. Las tonalidades cálidas del rojo y el ocre, vuelven a tener un protagonismo cromático muy intenso e invaden todo el lienzo con su presencia, dando cuerpo a la figura misma del santo.

El cuadro de «San Antonio de Padua con el Niño en brazos» (fig. 5) trae inmediatamente a la memoria el «San Antonio» del trascoro de la catedral de Burgos. Ahora bien, en el lienzo de Trevi la acción ha quedado reducida a los dos protagonistas, eliminándose, por lo tanto, el donante y el ambiente de interior del cuadro de Burgos. Sin embargo, en ambos casos, e igual que en el «San José» que hemos visto, el Jesús Niño se aproxima al santo con un gesto de ternura evidente, acariciándole el rostro. El rojo intenso del manto del pequeño, anteriormente blanco en el «San José», contrasta bellamente con el entenebrecido hábito del franciscano del que resalta, destacado en un centelleo de brillos, el cordón reglamentario ${ }^{45}$. Éste se curva hacia el interior de las piernas del santo, imprimiendo a la composición un sutil movimiento de balanceo, que nos permite imaginar un instante, en el que el santo mece al Niño, resaltando, de este modo, la ternura de la escena antes apuntada.

Finalmente, en el extremo derecho, cierra la capilla un cuadro representando una «Visión de San Francisco». Del mismo modo que en el «San Antonio», arriba estudiado, se hace inevitable la comparación con la tela, de asunto parecido, del trascoro de la catedral de Burgos. En este caso, se vuelve a repetir el mismo modelo físico de San Francisco, de rasgos enjutos, de fuerte realismo y con la mirada abstraída en el milagro. La composición en Trevi se resume y simplifica notablemente, de tal forma que desaparecen del lienzo el hermano León, el paisaje y el querubín que le imprime los estigmas. Ahora, solamente se produce el milagro de la aparición del Cristo crucificado a S. Francisco, que junta sus manos llagadas en el pecho y queda absorto ante la visión divina que emerge incandescente, de la oscuridad. En nuestra opinión, hay que destacar el sólido estatismo del santo, suministrado por la rectitud de su figura y la disposición paralela de sus pies desnudos. Junto a éstos y en la parte derecha, descansa un cráneo, esta vez con las órbitas oculares mirando hacia el espectador y que cierra la composición general de los seis santos ${ }^{46}$.

Dos años más tarde de haber trabajado en Trevi nel Lazio, en 1668, fray Juan Rizi se debió trasladar, por razones que todavía ignoramos, a la ciudad de L'Aquila (El Águila) perteneciente, en aquel momento, al Reino de Nápoles. Esta hipótesis que aún no hemos podido demostrar documentalmente, se basa, esencialmente, en una leyenda que el propio benedictino deja en uno de sus dibujos que se conservan en la biblioteca de Montecassino. Nos estamos refiriendo al jeroglífico que Rizi diseñó para el aniversario del nacimiento del rey Carlos II, en cuya parte inferior se puede leer lo siguiente: «En eruditisimo Museo de la Illustrisima Ciudad del Aguila del Catholicisimo Reyno di Napoles al festejo celebrado con universal aplauso a 6 dias del Mes de Noviembre del año 1668» ${ }^{47}$. Pensamos que este escrito se refiere al lugar y el día en que Rizi terminó de dibujar el jeroglífico, ya que el cumpleaños del rey era el día 11 de Noviembre.

45 En este lienzo que ha debido perder capa pictórica, se puede observar un «arrepentimiento». Obsérvese que el cordón franciscano caía originalmente recto, hacía abajo, y sin embargo el benedictino corrigió la trayectoria del mismo arqueándolo hacia los pies del santo, dando, de este modo, mayor dinamismo a la composición.

${ }_{46}$ En nuestra opinión, la composición del conjunto de los seis santos quedaría abierta por la calavera representada en la parte inferior derecha del lienzo del «San Carlos Borromeo», situado en el otro extremo de la capilla.

47 Manuscrito $n .^{\circ} 537$ de la biblioteca de Montecassino, folios 11 y 12 . 

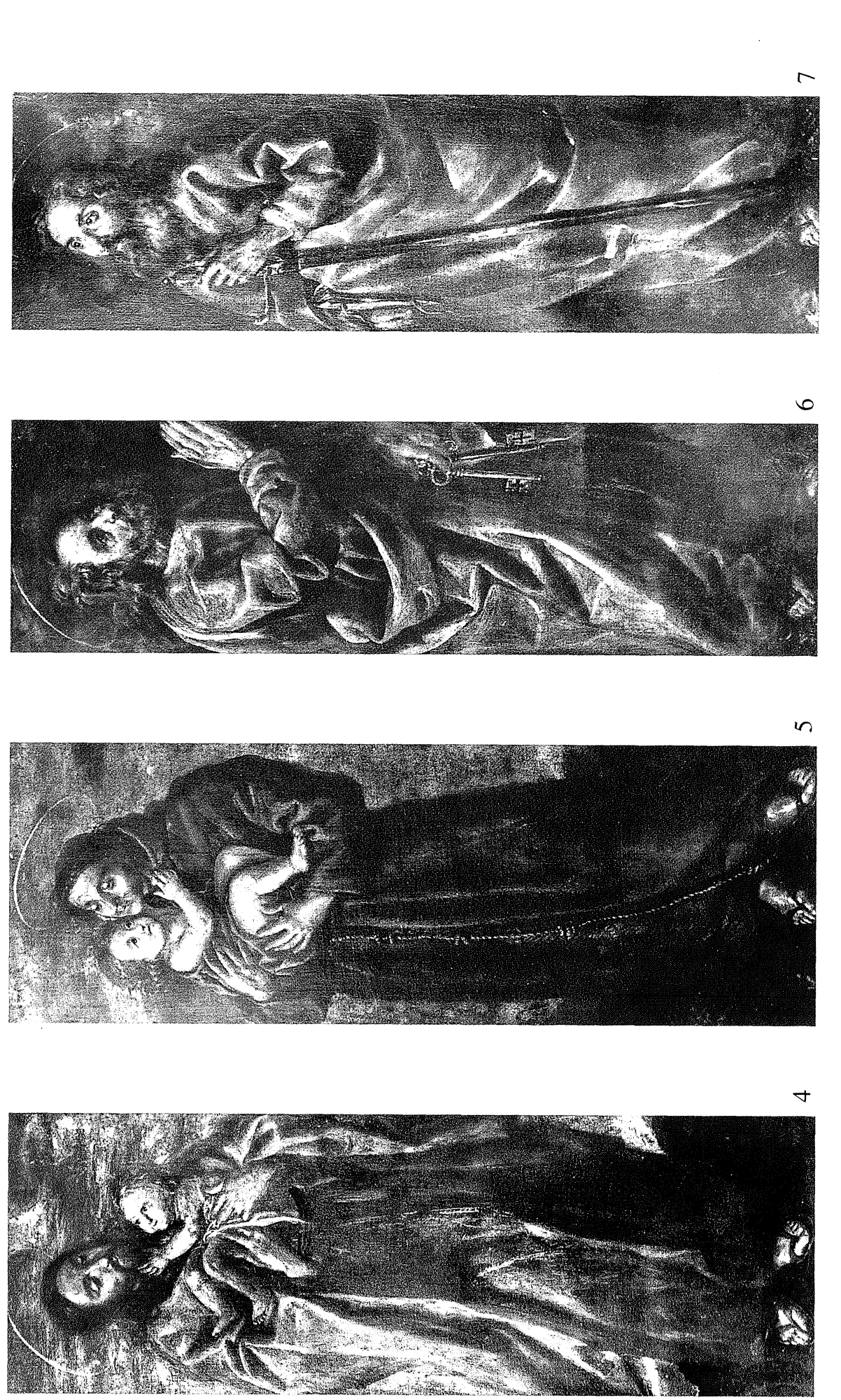
El jeroglífico, hecho con tinta marrón en las dos caras de una hoja blanca ${ }^{48}$, representa lo siguiente: en el anverso (fig. 8) un león rugiente subido sobre la esfera terrestre que, con sus cuartos delanteros, sujeta el Cáliz sobre el que flota una Hostia alada, a su vez, coronada por la tiara papal. Por encima del león, un águila se precipita sobre el felino y con las garras sujeta una filacteria que lleva una inscripción latina. La escena, eminentemente simbólica, está cercada de diversos textos en latín ${ }^{49}$, en español y de varios dibujos de querubines y pavos reales. En el reverso (fig. 9) de la hoja encontramos las mismas figuras aunque con algunas modificaciones, a saber: el león muerde una cruz, el águila ha cerrado sus garras, y muchas de las inscripciones latinas han desaparecido sustituidas por querubines y pavos reales.

En cuanto a los rasgos estilísticos del «jeroglífico», entendemos que fray Juan utiliza dos tipos de aproximaciones a la hora de la representación de los objetos: una, naturalista realista y, otra, figurativa con tendencia a la abstracción. Por lo que respecta a la primera de ellas, podemos decir que el león y el águila, descritos anteriormente, están representados de forma verosímil, imitando la anatomía de los animales de su especie. Respecto a la segunda aproximación que apuntábamos, figurativa con tendencia a la abstracción, fray Juan diseña los querubines y pavos reales a partir de líneas curvas, ondulantes y espirales que van construyendo las formas deseadas. Es decir, unas líneas sinuosas, en curva y contra curva sucesivas, que se rizan, ensortijan y que giran y avanzan casi sobre si mismas, componiendo los perfiles de querubines y pavos reales con un resultado muy decorativo, moderno y casi abstracto, sobre la línea misma.

En el mismo manuscrito en donde se incluye el jeroglífico a Carlos II, el benedictino realiza otros tres, esta vez, dedicados: uno a la Virgen ${ }^{50} \mathrm{y}$, los otros dos, a los Sumos Pontífices Clemente IX y Urbano VII ${ }^{51}$. El primero, como en el de Carlos II, ocupa las dos caras de una hoja blanca sobre las que el benedictino dibuja con tinta marrón. En el anverso de la misma (fig. 10) se representa una gran palmera, cargada de racimos de dátiles, que es una clara alusión al papel de la Virgen como figura alimenticia de Jesús en su tierna edad. Sobre ella, se sitúan tres discos rodeados de varias citas latinas, las cuales concéntricamente se adaptan a la curvatura de aquéllos y, a su vez, otras inscripciones, siempre en latín, se intercalan en el dibujo. En el reverso de la hoja (fig. 11) encontramos de nuevo, la palmera datilera aunque, en este caso, encima de ella aparece la Virgen de pie, desnuda pero cubierta por su larga cabellera, que amamanta al Niño, ambos circunscritos en un círculo solar del cual se despliegan dos alas. Todo ello se completa con diferentes filacterias y escritos latinos que se insertan en la composición.

48 Curiosamente, muchos de los dibujos de Rizi conservados en Montecassino, aparecen realizados por doble partida, es decir en el anverso y reverso de la misma hoja. Esto puede ser debido a que el pintor tenía intención de grabarlos más tarde y, por esta razón, repetía la composición, de forma invertida, para ver el efecto final que se produciría después de la impresión. En este sentido, vale la pena recordar las palabras de fray Juan en la, ya citada, carta dirigida a la Duquesa de Béjar: «y obedecí a escribir el libro, Imagen de Dios y de las Criaturas, que dedique a VE en lengua materna española, que es la castellana y aunque tenia escrito este mismo argumento en la materna de la Yglesia Catolica Romana, que es la Latina (trabajo que le fie de un discipulo mio D. Gaspar de Zuñiga... y aviendo ido este caballero con el Marques de Mancera Virey de la Indias, y abriendo mis dibujos en laminas de plata con tan nuevo corte que siendo de buril, no parecia buril, ni aguafuerte, sino mi pluma, del mismo modo que le dava el diseño, asi el abria, mas con su muerte, que senti con extremo celo y perdi, oleo y trabajo) mas (sin el) precepto de VE le e renovado de pluma y deseo abrirle de aguafuerte, que es el mas valiente modo de dibujar, y no quiero fiarle de otro buril, o grafia sino al de mi mano...... Manuscrito.$^{\circ} 590$ de Montecassino, folio 3. Esta interesante cita nos da pie a pensar que el mencionado D. Gaspar de Zúñiga, su discípulo, pudiera ser el autor de la obra «San Benito abad» en Santa María de Frómista, atribuida por Angulo y Pérez Sánchez a un discípulo de Rizi.

${ }_{49}$ Las citas latinas que aparecen en los dibujos de Rizi, en general, se refieren a textos bíblicos, principalmente salmos.

50 Manuscrito.$^{\circ} 537$ de la biblioteca de Montecassino, folios 9 y 10.

51 Manuscrito $n .^{o} 537$ de la biblioteca de Montecassino, folios 13 y 14. 

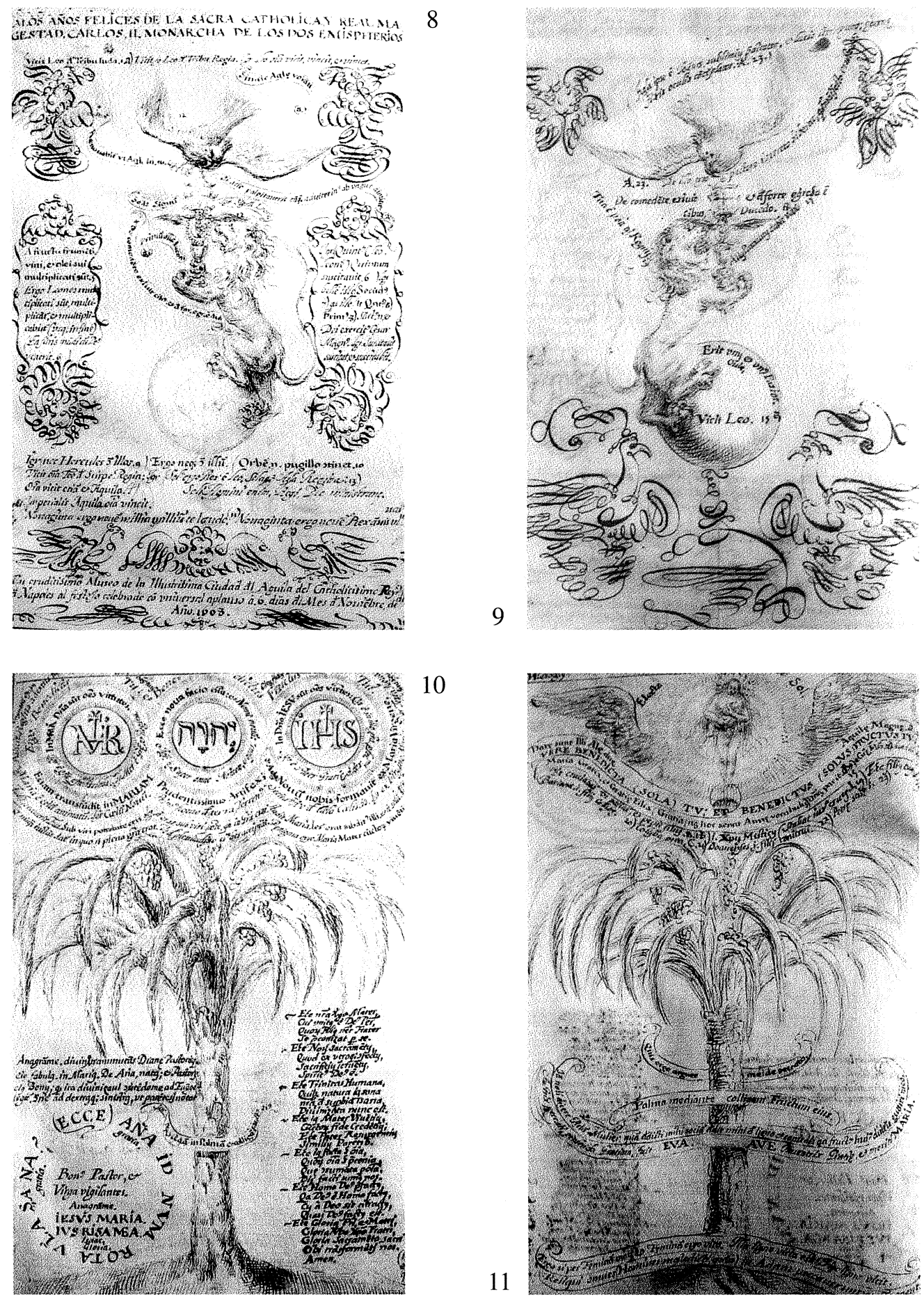

Figuras 8 y 9. Jeroglifico en el cumpleaños del rey Carlos II. Manuscrito n. ${ }^{\circ}$ 537, folio 12, anverso y reverso. Figuras 10 y 11 . Jeroglífico dedicado a la Virgen. Manuscrito n. ${ }^{2}$ 537, folio 9, anverso. Jeroglífico dedicado a la Virgen. Manuscrito n. ${ }^{9}$ 537, folio 10, reverso. Biblioteca de Montecassino (Italia), dibujos. 
Por lo que respecta a los jeroglíficos dedicados a los sumos pontífices Clemente IX ${ }^{52} \mathrm{y}$ Urbano VII ${ }^{53}$, hay que decir que en el anverso del folio 13 (fig. 12) se representa el del papa Clemente mientras que, en el reverso del mismo, el de Urbano VII (fig. 13). El primero de ellos muestra en su centro el Cáliz sobre el que flota la Hostia como círculo solar, y todo el conjunto, coronado con la mitra papal. En los laterales del dibujo, encontramos dos ángeles de cuerpo entero y dos querubines voladores. La composición se completa con filacterias e inscripciones latinas alusivas al cuerpo, la sangre de Cristo y al papa Clemente. En cuanto al jeroglífico del papa Urbano VII, la hechura es casi idéntica. Se reduce el número de inscripciones latinas y, en el centro de la Hostia, se distinguen cuatro cuarteles que encierran, cada uno de ellos, varios símbolos heráldicos, a saber: el águila y el puercoespín de la familia Ricci, corazones y bandas diagonales de la familia Guevara, unas castañas de la familia Castaña y, finalmente, unas llaves que deben hacer referencia a la cátedra de San Pedro ${ }^{54}$.

Sobre este dibujo, merece la pena destacar la belleza y la modernidad con la que están ejecutados los ángeles de cuerpo entero. Y debe observarse que vuelve a utilizar, como en otras ocasiones, la línea curva como elemento único compositivo que proporciona, a las siluetas, el volumen, la luz, la sombra, el movimiento... De tal modo que el trazo, en un desplazamiento espiral, va creando los contornos de las formas, las cuales van quedando huecas en su parte interna. Los ángeles parecen estar elaborados gracias a la unión de diversos resortes que, «soldados» unos a otros, construirían los brazos, las piernas y, en general, el conjunto de la figura angélica, dejándola vacía en su interior, para imprimirle, si cabe, un espíritu translúcido, ligero, aéreo. Son, sin duda, imágenes con complexión y estructura pero, al mismo tiempo, con un marcado componente abstracto.

Otro dibujo incluido en el códice n.․ 537 es la ilustración que hace Rizi al Éxodo (fig. 19), en cuya parte superior aparece la siguiente inscripción: «Lapis inventus anno Domini. 1669 Aprilis II in Aquila civitate luce umbraque; saxea a Domino Apel ${ }^{\circ}$ depictus. 7 die quo omnia creavit quem infideles aspiciant et credent»... Probablemente sea un dibujo preparatorio para un aguafuerte, que también estuviera hecho en la ciudad de L'Aquila, esta vez, en $1669^{55}$. Este diseño, sin duda uno de los más impresionantes del benedictino, se nos presenta como si de una visión onírica se tratara: caballos encabritados y serpientes voladoras cruzan la composición rodeados de seres ectoplásmicos, cuyo significado no alcanzamos a comprender con toda precisión. Las figuras, en algunos casos, se construyen unas por extensión de otras, giran, se alargan, se retuercen y bucean en lo que nos parece el paso del Mar Rojo ${ }^{56}$. Todo este revuelo y confusión lo observa, desde el ángulo superior derecho, la Virgen con el Niño rodeada por pequeñas nubes de puti, enmarcados, todo ellos, en un resplandor. Debajo del resplandor ${ }^{57}$, un ángel de cabellos erizados, abre uno de sus brazos para mostrarnos la inquietante y estremecedora escena.

52 Julio Rospigliosi fue papa desde el 1667 al 69, años en los que, probablemente, Rizi llevó a cabo su jeroglífico.

53 Juan Bautista Castaña Ricci (1521-1590). Hijo del noble genovés Cosme Castagna y de Costanza Ricci, romana de origen florentino y hermana del cardenal Jacovazzi. Su papado duró 13 días, no llegó a ser coronado y fue enterrado en Santa María Sopraminerva. (El sepulcro es obra de Ambrosio Buonvicino).

${ }_{54}$ Fray Juan incluye este papa porque es un Ricci, por lo tanto antepasado suyo, y en homenaje al mismo.

55 Tormo solamente publicó el reverso de este dibujo en donde no aparece la inscripción citada. Tormo, Gusi, Lafuente, Obra cit. Madrid 1930, vol. I, lámina CLVII. En relación con la técnica de grabado utilizada por Rizi, véase nota n. ${ }^{4} 4$.

${ }_{56} \mathrm{Al}$ pie del dibujo, en el margen, se puede leer «Éxodo 15», que corresponde al «Canto Triunfal» después del paso del Mar Rojo. En Éxodo 14, versículos 15 y 16, se lee lo siguiente: «Dijo Yahvéh a Moisés: «ipor qué sigues clamando a mí? Di a los hijos de Israel que se pongan en marcha. Y tú alza tu cayado, extiende tu mano sobre el mar y divídelo...» Efectivamente, la figura de Moisés se diferencia perfectamente en la composición: el hombre de barba larga y blanca que mira al cielo y alza su cayado.

57 La aparición de la Virgen en la obra escrita y plástica de fray Juan es constante. En este caso, se muestra en una iconografía muy singular, pues la Virgen y el Niño son testigos de una escena del Antiguo Testamento. 

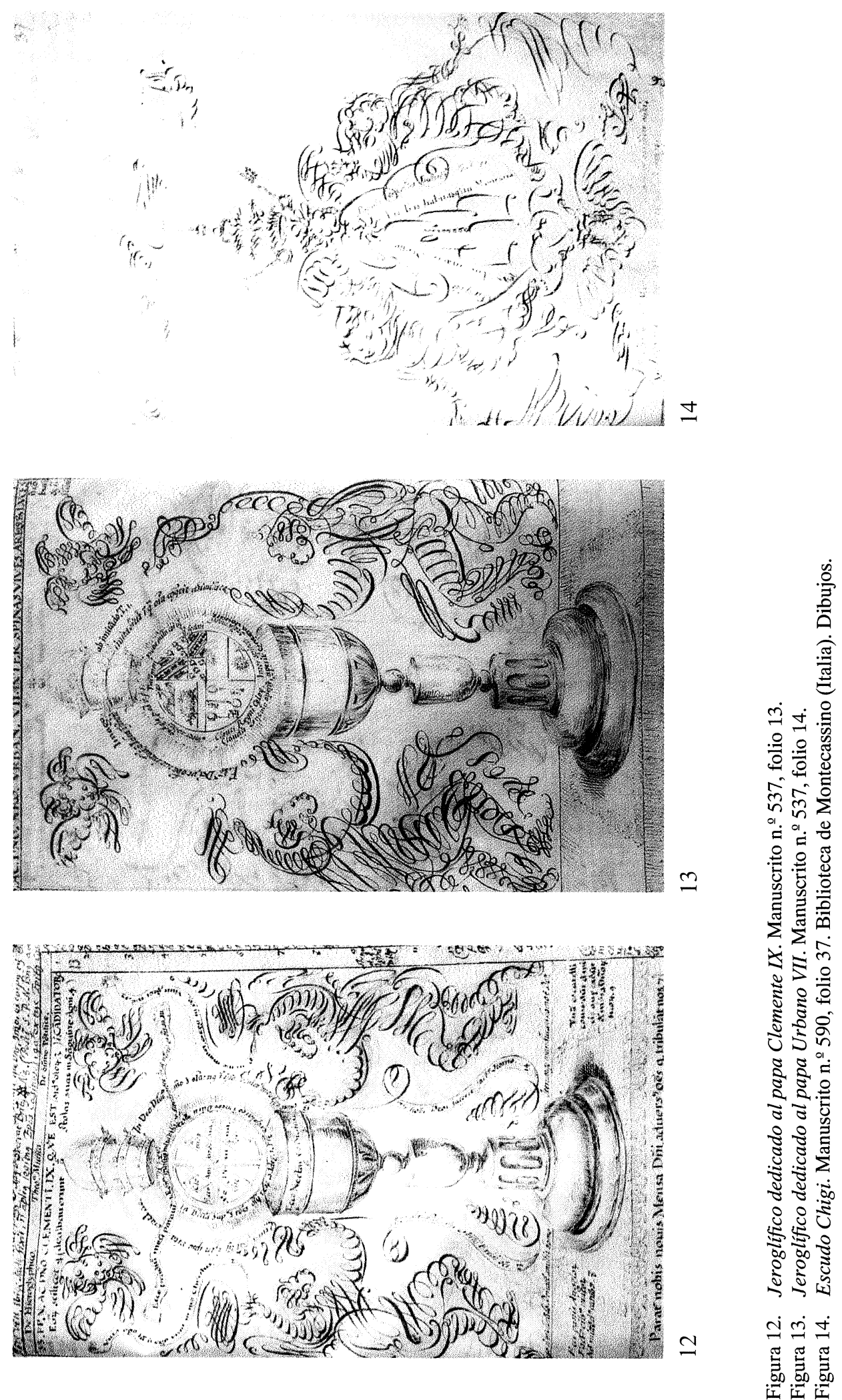
Estilísticamente el dibujo, gracias a sus poderosos contrastes lumínicos, está perfectamente en consonancia con el fragor y sobrecogimiento de la acción que se presenta. Un fuerte rayado en retícula oscurece el fondo de la composición y al mismo tiempo perfila y enmarca los cuerpos de las formas, proyectándolas fuera del plano. Estos volúmenes quedan graduados magistralmente, con trazos nerviosos y abreviados de la pluma que, a su vez, imprimen dinamismo y agilidad a la composición. En nuestra opinión, es un dibujo espléndido por la capacidad de Rizi de, con pocos recursos, crear una escena tan dinámica, con deformaciones de gran efectismo y que, sin duda, anticipa, por su carácter visionario, las realizaciones de pintores prerrománticos como William Blake o Füssli.

En los libros dejados por fray Juan en Montecasino, a parte de los diseños arriba estudiados y los publicados por Tormo y el padre Gusi, existen otros dibujos, hasta ahora no conocidos, que ilustran los citados manuscritos y que, por su importancia e interés, iremos analizando brevemente, en las siguientes páginas. Sobre este particular debe señalarse que, en el códice n. 590 de la biblioteca casinense, Rizi aborda diversos asuntos que van desde el conocido Epítome de Arquitectura del Orden Salomónico Entero hasta un Tratado de Moral escrito en castellano y dedicado a la Duquesa de Béjar ${ }^{58}$. Asimismo, descubrimos los retratos apoteósicos de la reina Cristina de Suecia, del papa Alejandro VII y otros diseños de asunto religioso, todo ellos dados a conocer por Gusi ${ }^{59}$. En cuanto a los nuevos dibujos, se pueden ver: un bello escudo de la familia Chigi (fig. 14) realizado con la técnica serpentinata que fray Juan utiliza en sus hechuras más abstractas; un retrato de Urbano VII (fig. 15) en cuyas partes superior e inferior unos puti sujetan la tiara papal y las llaves de la Iglesia; un retrato de Alejandro VII (fig. 16) junto a su escudo papal; otro de la beata Catalina Ricci (folio 46) y una representación, creemos, de San Benito (fig. 17). Todos están encerrados en perfiles ovales, llevados a cabo con una técnica suelta y naturalista ${ }^{60}$.

Por lo que respecta al tema religioso, fray Juan realiza en el mismo volumen, dos fondos ovales, el uno con «Cristo mostrando el Cáliz y la Hostia» (folio 41) y, el otro, con la «Virgen amamantando al Niño» (folio 41). Asimismo, lleva a cabo un dibujo, a página entera, de toda la familia de Jesús, y al que se incorpora una serie de inscripciones latinas sobre los protagonistas (figs. 18 y 20). Tal y como si fuera un retrato de familia se presenta, de izquierda a derecha y sentados, a San José con la vara florida, a Cristo resucitado mostrando el Cáliz y la Hostia, a la Virgen que amamanta al Niño, a Santa Ana aproximándose al pequeño y a San Joaquín en posición orante. Todos ellos, sobrevolados por querubines que juguetean entre filacterias, mientras que Cristo y la Virgen apoyan sus pies sobre una nube de querubines apiñados entre sí.

58 Este texto se inicia de la siguiente manera: «Es la ynclinación de VE a saber, que no hay cosa que se le esconda, solo la lengua latina, por no averse VE dado a ella, y con todo eso e visto entiende algo de ella quando reza o la oye hablar, porque en la lengua castellana se puede enseñar todas las sciencias, para que logre VE su inclinacion, reducire a breves sentencias las noticias de ellas, y porque la de materias morales las tocan todos en las mismas obras que hacen sera la primera». Manuscrito $n .{ }^{\circ} 590$ folio 51.

59 Tormo, Gusi, Lafuente, Obra cit. Madrid 1930, vol. I, láminas: CLIX, CLX, CLXI y ss.

${ }^{60}$ A diferencia de los otros manuscritos de fray Juan en Montecassino, el códice 590 está casi en su integridad escrito en castellano. En éste, el benedictino explica a la duquesa una gran diversidad de conceptos, tales como: los arrendamientos, los contratos de compañía, el cambio, la usura, la compra venta, la prenda, el salario de los criados... También se incluyen un tratado de Retórica y otro de Dialéctica, entre otros textos. Debe señalarse que el trabajo que supondría estudiar, con un nivel científico apropiado, los manuscritos de Rizi en Montecassino, equivaldría al esfuerzo que exigiría, por lo menos, una tesis doctoral. Por esta razón, muchos de los aspectos, de carácter iconográfico, de contenido teórico... tendremos que dejarlos solamente indicados, en espera de poder estudiarlos más adelante. 

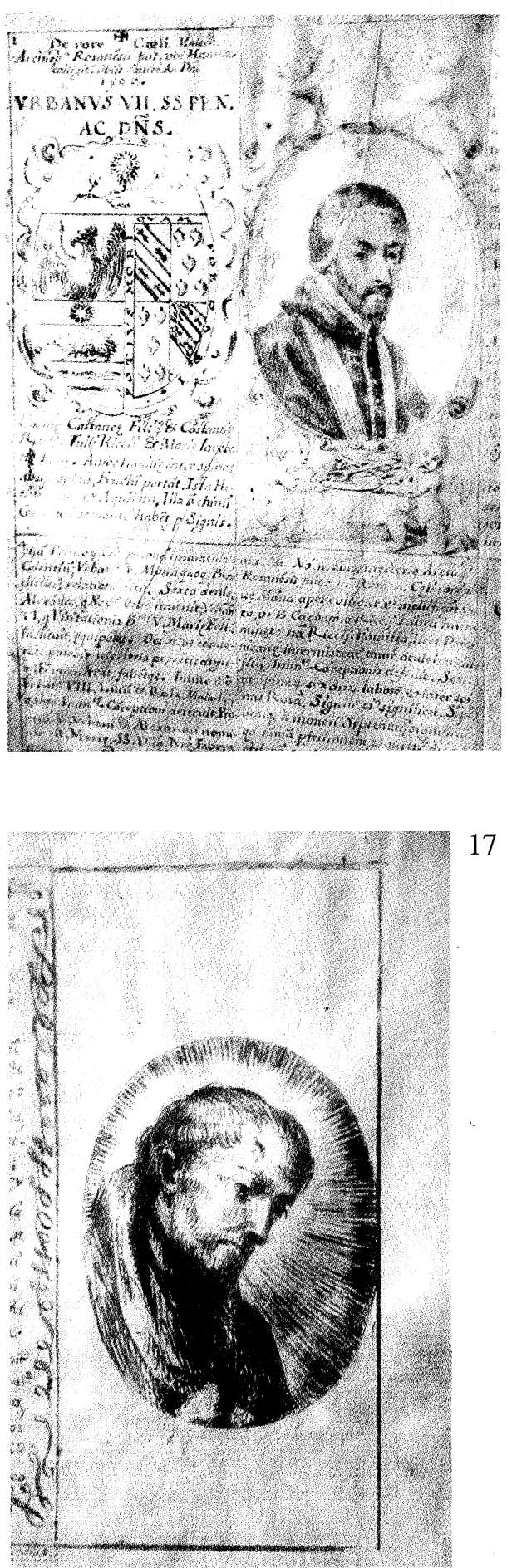

17
15
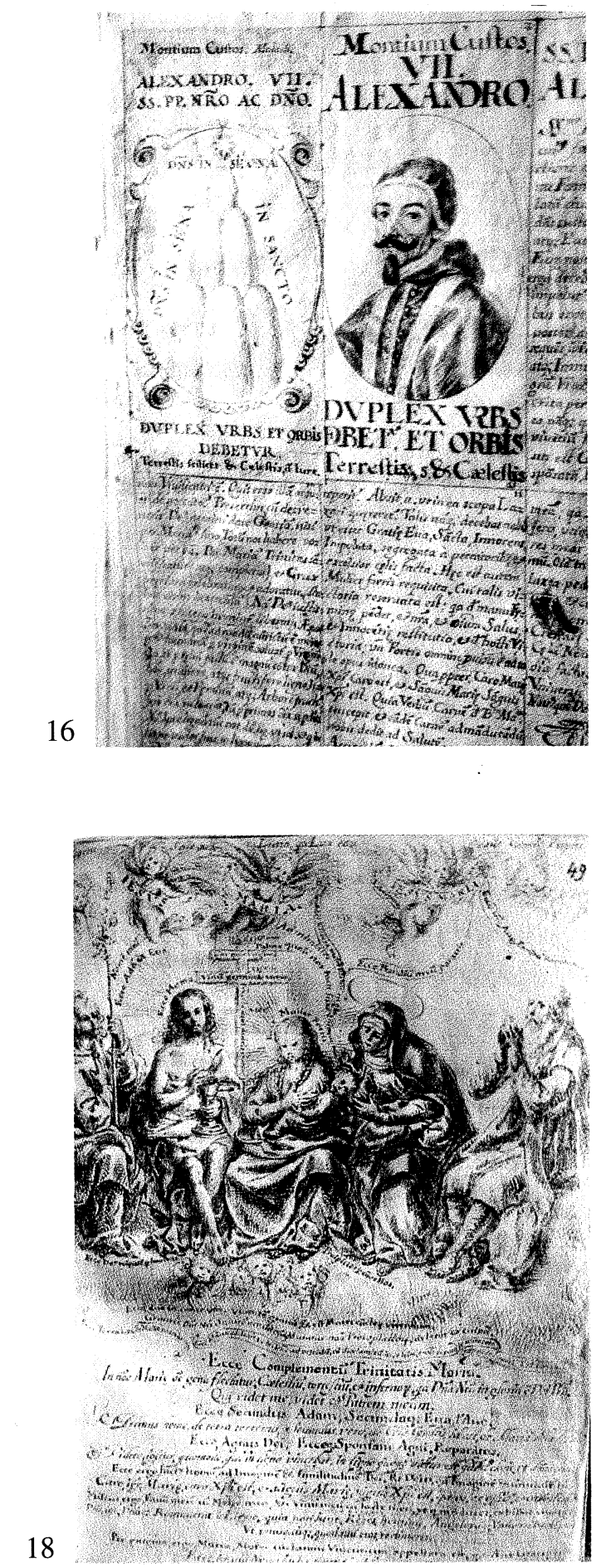

Figura 15. Retrato del Papa Urbano VII. Manuscrito n. ${ }^{\circ}$ 590, folio 38.

Figura 16. Retrato del Papa Alejandro VII. Manuscrito n..$^{9} 590$, folio 40.

Figura 17. San Benito? Manuscrito n. .590 , folio 47 , anverso.

Figura 18. Sagrada Familia. Manuscrito n. ${ }^{\circ}$ 590, folio 49. Biblioteca de Montecassino (Italia). Dibujos. 
Estilísticamente, este dibujo es claro reflejo de la técnica pictórica de Rizi, es decir, de fuertes contrastes lumínicos, amor al natural, factura suelta y plástica, claro y sobrio en la composición, monumental y corpóreo en los modelos. A éstos los viste con hábitos cuajados de plegados, angulosos, «acartonados» y, en ocasiones, aparatosos, por lo que dan fuerte volumetría, peso y solidez a sus figuras. Frente a la presencia casi estática de la Santa Familia, los querubines en la parte superior revolotean y se arquean entre las filactéreas, enmarcando la escena principal. Finalmente, merece la pena resaltar, no solamente de este dibujo sino también de los otros arriba citados, el carácter individual con el que fray Juan realiza los rostros de sus modelos, llamando la atención sobre el de la Virgen, a la cual, en esta última composición, le dibuja dos trenzas que recorren su cuello, como si fuera una mujer germánica ${ }^{61}$.

Dentro del códice n.. 590 también podemos observar un dibujo de un ave (fig. 21), para nosotros indeterminada y casi quimérica, que está ilustrando el folio 217 , en donde se explica el concepto de falacia. De nuevo, nos encontramos ante un diseño ejecutado velozmente, de bella abstracción, modernidad y expresividad. Finalmente y también incluido en este volumen, podemos ver el dibujo de un cometa que avistó el benedictino desde Roma, el 6 de enero de $1665^{62}$, que lógicamente no tiene un interés artístico en sí mismo, pero que es un ejemplo claro de la diversidad de inquietudes y dimensión científica del padre Rizi.

El manuscrito n. ${ }^{\circ} 469$ de la biblioteca casinense es el más ilustrado de todos los que, en ella, dejó fray Juan ${ }^{63}$. Gran parte de sus dibujos ya fueron publicados por el padre Gusi, sin embargo existen otros, en el mismo volumen, de buena factura, muy interesantes y todavía desconocidos. Nos referimos, por ejemplo, al de la «Virgen con el Niño bendiciendo junto con N. ${ }^{\circ}$ S. ${ }^{\circ}$ resucitado mostrando el Cáliz y la Hostia» ${ }^{64}$ (fig. 22), los tres sobre la esfera terrestre en la que se clava la cruz y cada uno coronado con la tiara. Este es un diseño en que se vuelve a observar la complejidad iconográfica de las composiciones de Rizi, en donde reúne tres personas que jamás pudieron estar juntas ${ }^{65}$. En el folio 69 encontramos un dibujo de «N. ${ }^{a}$ S. ${ }^{a}$ con el Niño, Cristo resucitado con el Cáliz y la Hostia» (fig. 23), todos detrás de un altar, en donde se apoya una cruz y un plato sobre un tapete y en cuya parte delantera se arrodillan dos querubines en actitud orante. De este diseño, merece la pena destacar, de una parte, el carácter hierático, los ricos hábitos y joyas con los que van vestidos y coronados los protagonistas, circunstancia que permite pensar en imágenes icónicas, como si formaran parte de un paso de Semana Santa. De otra parte y en el primer plano, dos querubines, cuyas alas brotan incluso de debajo de sus orejas, entran en la composición diagonalmente, agolpándose en los ángulos inferiores de la escena. Sus vestidos están tallados por fuertes sombras y sus pares de alas se pliegan y despliegan, hacia adelante y atrás, de un modo muy teatral. Son dos figuras de bella factura que suministran a la composición estabilidad y profundidad.

${ }^{61}$ Sobre este aspecto, en nuestra opinión, fray Juan debió sentir gran admiración por la obra de Durero pues coincide, con el germano, en el interés por la representación de las constelaciones, los animales, la anatomía humana, algunos aspectos de la arquitectura.... En este sentido, no se puede olvidar, cierta aproximación estilística de fray Juan hacia Durero y al mundo germánico en general, en la utilización de los vestidos de plegados angulosos y acartonados.

${ }_{62}$ Véase nota n. ${ }^{\circ}$ 16. En el dibujo se puede leer el siguiente texto: «La gente del campo decía que les daba tanta luz como la Luna. Propiamente es una estrella dentro de una luna muy clara y circular y un dragon que recive en la boca su luz. Ojala toda la morisma la reciva de la Luna de la Yglesia» Ms 590, folio 374.

63 Véase nota n..$^{9} 18$.

64 Folio 67.

${ }^{65}$ Obsérvese que la Virgen representada es N..$^{\text {a }}$ S. ${ }^{\text {a }}$ del Popolo, cuya imagen se venera en la basílica de Sta. María la Mayor de Roma. 

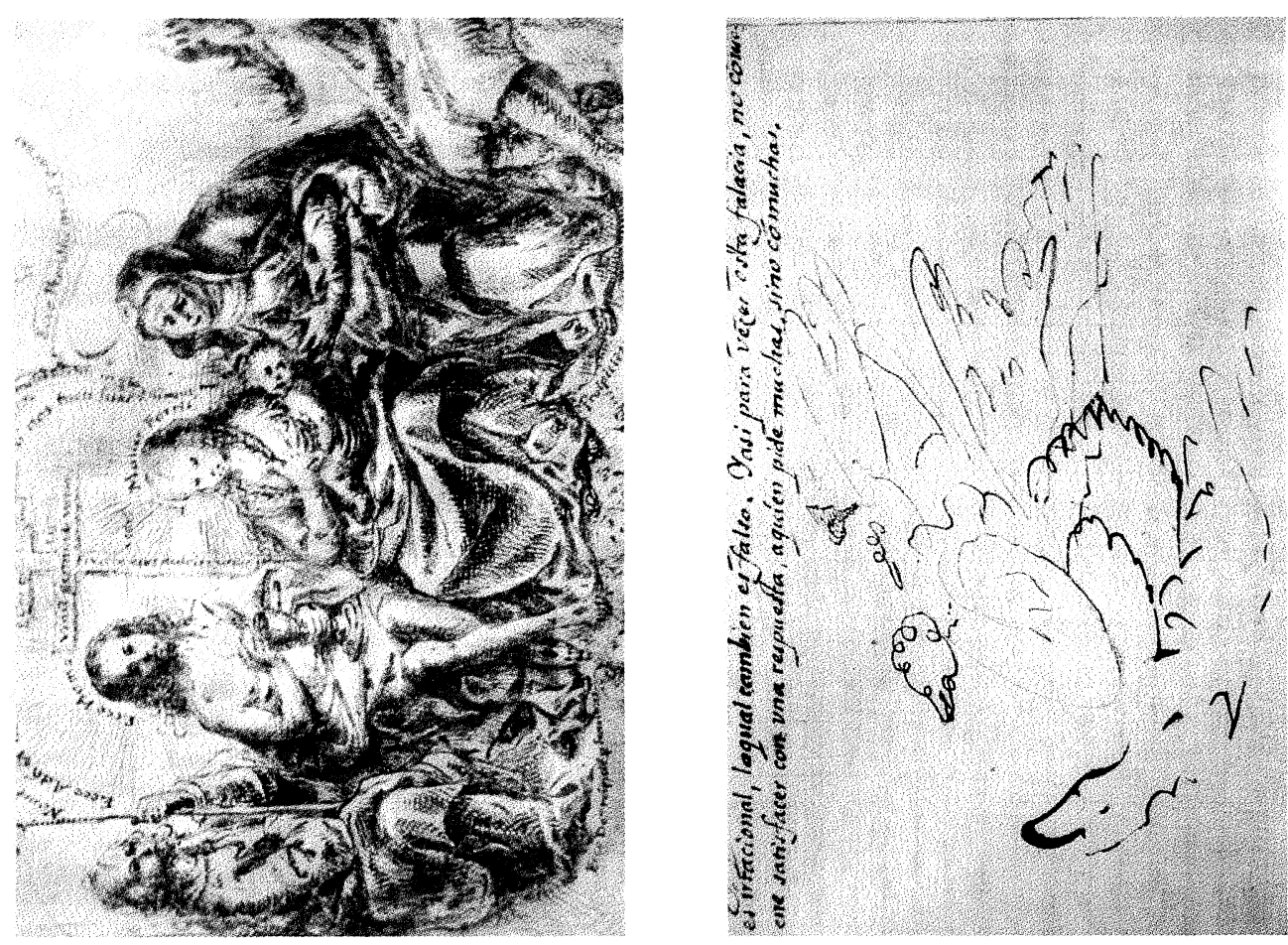

ㅇ

$\overrightarrow{4}$

2

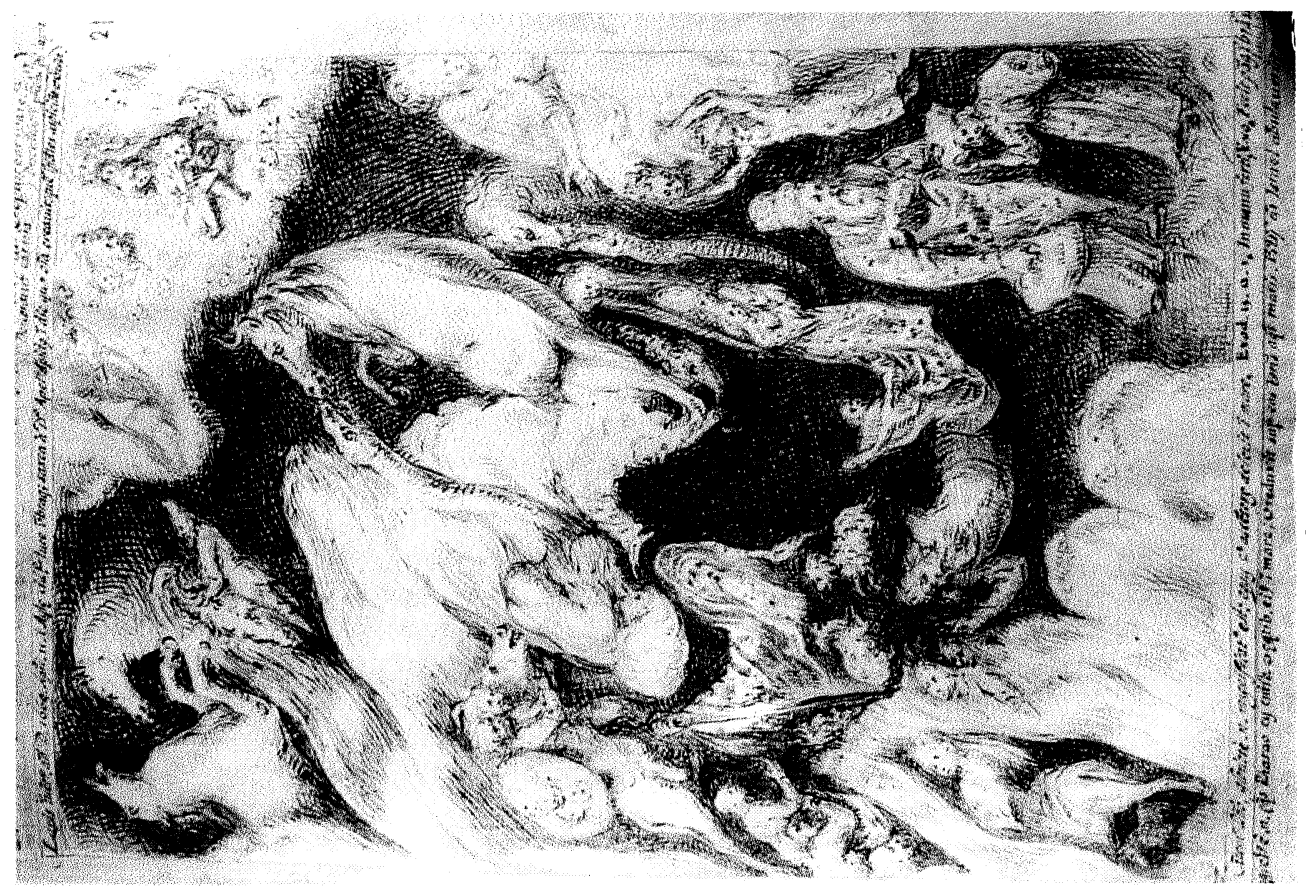

守

구웡

융 众造

西,

กิ่

a.

을

들 융

高

$\therefore$ क a

อ.

용

\& 8

ङ

จंतेंते

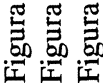


Otro dibujo inédito, incluido en el códice 469, es el del folio 79. En él se representa a «Cristo resucitado con el Cáliz y la Hostia, la Virgen y el Niño» (fig. 24) los tres coronados con la tiara, detrás de un altar, en donde se apoya una cruz y delante de cuyo frontal se sitúan dos querubines en acto de adoración. Las santas imágenes son monumentales, los querubines del primer plano muy decorativos, con sus alas extendidas en abanico, y los ángeles de la zona superior, golpeados de luces y sombras, se disponen de forma descendente, diagonalizando y, a su vez, dinamizando la composición. Además, Rizi dibuja unas bandas horizontales en la parte posterior de la escena, para representar unas multitudes celestiales que, en lontananza y sobre nubes, parecen ser testigos y celebrar el acontecimiento. Estas multitudes están dibujadas magistralmente, gracias a pequeños golpes de tinta, de factura nerviosa y abreviada, que nos hacen recordar, de algún modo, la hechura, también resumida, de las once mil vírgenes en el lienzo de «Santa Victoria» del trascoro de la catedral de Burgos.

Igual que en el tratado de Pintura Sabia, en el códice 469, también encontramos dibujos explicativos sobre el modo cómo deben representarse las figuras femeninas y masculinas en sus diferentes escalas, edades, distribuciones musculares, etcétera. Asimismo, muchos de los textos vienen ilustrados con pequeños dibujos, intercalados entre los párrafos, que representan temas bíblicos como, por ejemplo: «el Arca de Noé» (folio 91) y «el Arca de la Alianza» (folio 193), entre otros. A su vez, vale la pena recordar los dibujos, ya publicados ${ }^{66}$, que recrean pasajes del Génesis como la «Creación de Adán», «de Eva» o del «Paraíso Terrenal», en los cuales el maestro benedictino demuestra un buen dominio del dibujo de desnudo y de paisaje ${ }^{67}$, géneros, por otra parte, tan ausentes en nuestra pintura del Siglo de Oro. En ellos, podemos ver la facilidad con la que Rizi representa el reino animal: caballos, elefantes, leones, todo tipo de aves, ballenas, delfines... a los que da volumen gracias a sombras hechas con líneas en cuadrícula. La naturaleza está captada con gran frescura, atmosféricamente, presentándose los primeros planos con contornos bien delineados y las regiones más lejanas del dibujo se abocetan y resumen de un modo muy sintético, pero con gran sensación de realidad.

Siguiendo con los manuscritos casineses, es justo recordar algunos de los dibujos del códice n. ${ }^{\circ}$ 545. En su folio número 15, descubrimos un diseño explicativo sobre el «Arca de Noé», ya flotando en las aguas del diluvio, en el cual el benedictino expresa gráficamente cómo se distribuían los espacios de vivienda del Arca, las dimensiones y capacidad de la misma, etcétera. Otro dibujo aclaratorio, aunque con mayor valor artístico, es el del folio 25 , en el que vemos el «Arca de la Alianza» (fig. 25) y un guión explicativo de cada elemento representado. De nuevo, es interesante observar la hechura casi «conceptista» con la que Rizi resuelve los ángeles que depositan las Tablas de la Ley, en el fondo de la composición. En el primer plano, dos esbeltas figuras angélicas custodian el Arca, en actitud orante, con sus alas extendidas armoniosamente, como ya hiciera, nuestro pintor, en otras ocasiones.

Fray Juan sigue ilustrando, en este códice, diferentes elementos en relación con el Antiguo Testamento: el «candelabro de los siete brazos» (folio 26), el «altar del holocausto» (folio 26), las «Tablas de la Ley» (folio 27), los «hábitos del Sumo Sacerdote» (folio 28) y la planta y algunos alzados del «Templo de Salomón» (folios 49, 51, 52). Este templo estaba cercado por dos murallas y en su centro se colocaba el altar para los sacrificios. El frente principal del templo era el oriental, en donde se disponían sucesivamente dos puertas, de las cuales Rizi proyecta la fachada. Ambas, con dos torres amerlonadas, tienen un carácter, como todo el edificio, de

${ }^{66}$ Tormo, Gusi, Lafuente, Obra cit. Madrid 1930, vol. I, láminas CXLI, CXLII, CXLIII, CXLIV, CXLV, CXLVI, CXLVIII y ss.

${ }_{67}$ Quizá Rizi no llegue a la poética paisajística del famoso Dughet, pintor coetáneo suyo, pero alcanza un nivel de belleza y perfección digno de cualquier discípulo suyo como, por ejemplo, Crescenzio Onofre, a quien, en nuestra opinión, supera. 


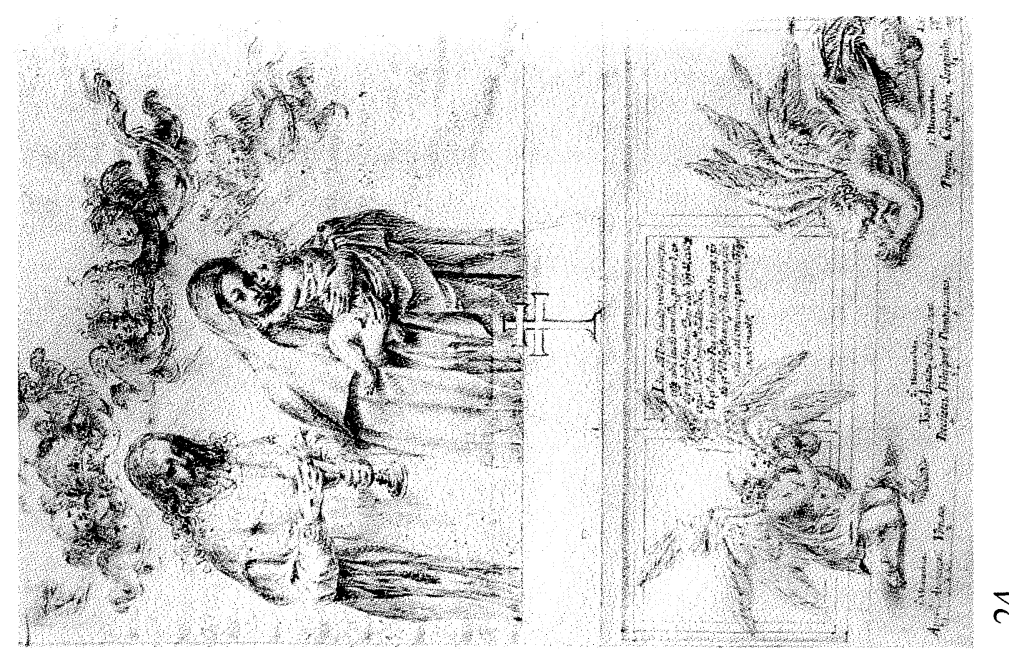

オ
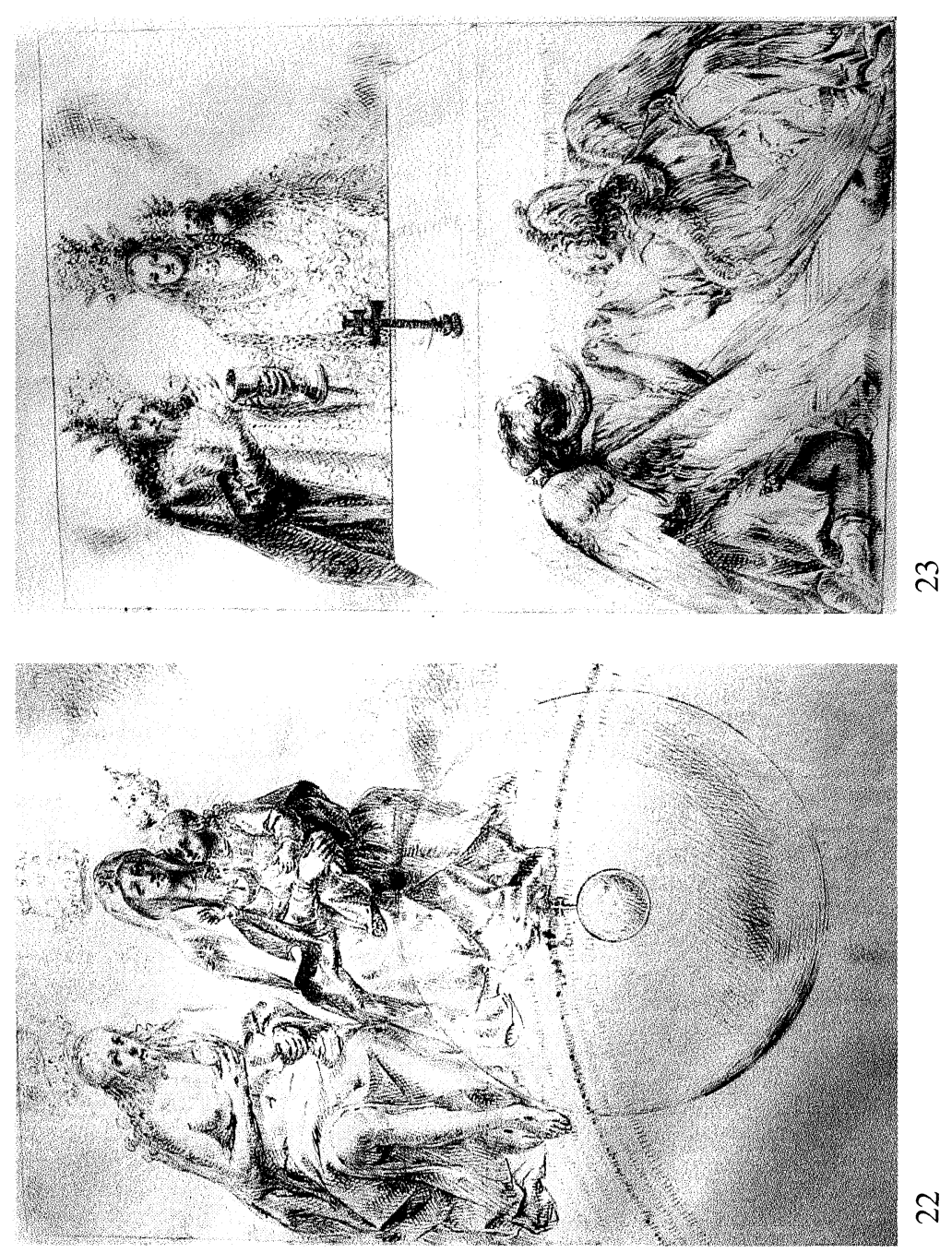

त) व व

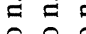

융유

要品

党 $\sum_{\Sigma}$

完完

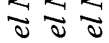

को तो जो

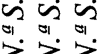

8ี 8ี

\&

氖

己ิ

ส

高离部 
fortaleza defensiva ${ }^{68}$ (figs. 27 y 28). Finalmente, en el mismo manuscrito, volvemos a encontrar los retratos del papa Urbano VII, de Catalina Ricci ${ }^{69}$ y, otro nuevo, de Francisco Ericius, Dux de Venecia en 1633 (fig. 26). En nuestra opinión, este último dibujo muestra dos aspectos fundamentales en la técnica de Rizi: su economía de líneas a la hora de la representación y su capacidad en la individualización del rostro humano. En relación con este dux veneciano, es interesante recordar el cuadro «el Cardenal», atribuido a Rizi, de propiedad particular, cuyo modelo físico encontramos muy parecido al de Francisco Ericius ${ }^{70}$.

Otros manuscritos llevados a cabo por Fray Juan son el n. 470 y el n.. 544 . En el primero, que es un comentario a la Sagrada Escritura en latín, se incluyen los diseños del palacio de Salomón, cuyas fachadas presentan un gran parecido con el edificio que aparece al fondo del cuadro, de «los martirios de las Santas Céntola y Elena», en el trascoro de la Catedral de Burgos. Es un edificio (folio 221) de dos pisos, levantado sobre una base de sillares, probablemente cortados en anglete con el fin de que no se perciban las juntas, tal y cual el benedictino explica en sus escritos. El primer piso presenta una hilera de vanos, con uno central más amplio, coronados con frontones curvos. El segundo nivel también está concebido como una sucesión de ventanas, aunque esta vez con frontones triangulares y bajo una cornisa amerlonada ${ }^{71}$. Del manuscrito n. 9544 , que está en relación con la matemática y la geometría, cabe señalar algunos dibujitos que el fraile debería hacer en momentos de reflexión relajada, como por ejemplo, un dragón que está decorando una tabla matemática (folio 161) o el de un pequeño navío en un margen de una hoja (folio 114). Además en este volumen, en el que se incluye un tratado de medicina, se inserta un repertorio de todos los escudos de las órdenes militares bajo la regla de San Benito ${ }^{72}$.

En conclusión, podemos decir que fray Juan Rizi es una de las personalidades más interesantes de la pintura y el pensamiento españoles del segundo tercio del siglo XVII. Su labor artística se desarrolló principalmente en Castilla la Vieja y la Rioja y representa, a través de su estilo naturalista y tenebrista, un papel similar al que los pintores como Jerónimo J. Espinosa o el propio Zurbarán llevaron a cabo en Valencia y Sevilla, respectivamente. A pesar de ser un pintor en muchos aspectos documentado, todavía desconocemos su periodo inicial de formación, toda la obra que realizó antes de los 41 años y gran parte de la que suponemos que compuso en Italia, aproximadamente a partir de 1670. A este respecto, los ocho nuevos cuadros pintados en 1666, en la colegiata de Santa María Assunta de Trevi nel Lazio, ponen en evidencia que el estilo del benedictino continua la misma trayectoria, ya iniciada en España, de un tenebrismo y naturalismo muy personales, que combina con una serie de sujetos iconográficos muy singulares, a buen seguro sorprendentes para la Italia del momento, y de explícita devoción mariana. De todo ello son claro ejemplo sus dibujos dejados en Montecassino, aún muy poco estudiados y valorados en el conjunto del dibujo español del Siglo de Oro, los cuales, en algunos casos, sorprenden por la modernidad de su invención, la complejidad alegórica de sus asuntos, y por el dominio de Rizi a la hora de la representación del paisaje y la anatomía humana y animal.

${ }^{68}$ Queremos recordar las palabras de Rizi en su Epitome de Fortificatione Architecturae Subalterna... en el códice n. .590 de Motecassino, folio 5, en donde propone la fortificación de Roma: ...«a su tiempo dare un tratado con el auxilio Divino contra los enemigos de la iglesia, para defensa de la Ciudad mas fuerte, como defendida sobrenaturalmente, porque se defienda tambien naturalmente. Que es genero de piedad contra rebeldes y tiranos, parecer crueles..» Como es lógico, todos estos dibujos hacen referencia al libro primero de los Reyes, incluido en la Biblia, en donde se narra la construcción del templo de Salomón.

${ }_{69}$ Estos dos retratos, como hemos visto, ya los había reproducido en el manuscrito n. ${ }^{\circ} 590$. A su vez, aparecen los escudos de Urbano VII, de la familia Erice y el de un obispo, en cuyos cuarteles se ven los componentes heráldicos representantes de las familias Ricci y Guevara. Sobre este último, Gusi supone que puede hacer referencia al posible obispado concedido a fray Juan por Alejandro VII. Tormo, Gusi, Lafuente, Obra cit. Madrid 1930, vol. I, folio 45.

70 Angulo, Pérez Sánchez, Obra cit. Madrid 1983, lámina 298.

71 También incluye en este texto, el proyecto de los capiteles que se colocaban encima de las columnas de bronce del palacio de Salomón. Folio 224.

72 En relación con este dibujo, se puede poner el cuadro de «San Benito y las órdenes militares» en San Millán de la Cogolla. 

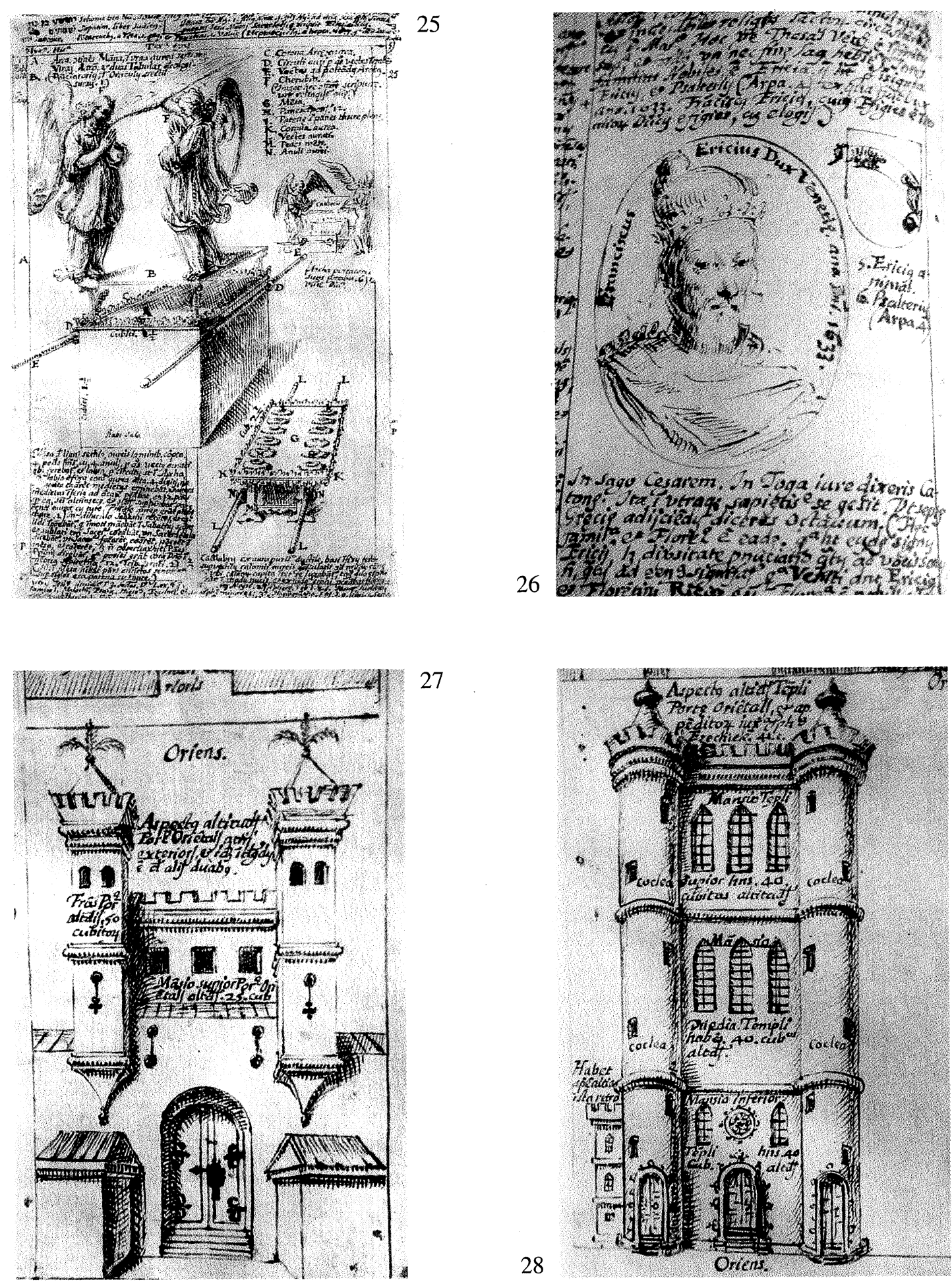

27

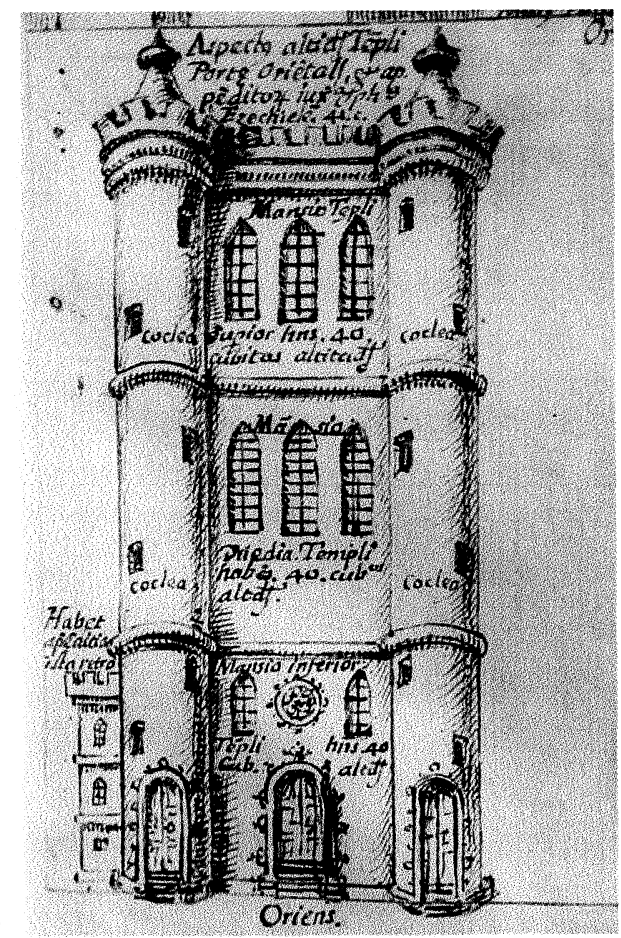

Figura 25. El Arca de la Alianza. Manuscrito n. ${ }^{\circ}$ 545, folio 25.

Figura 26. Dux Franciscus Ericius. Manuscrito n. ${ }^{\circ}$ 545, folio 37.

Figura 27. 1. ${ }^{\underline{a}}$ puerta de acceso al Templo de Salomón. Manuscrito n. ${ }^{\circ} 545$, folio 49.

Figura 28. 2. ${ }^{g}$ puerta de acceso al Templo de Salomón. Manuscrito n. ${ }^{9} 545$, folio 49. Biblioteca de Montecassino (Italia). Dibujos. 
Además de pintor y monje benedictino de vida ejemplar, sus inquietudes intelectuales invadieron numerosas regiones del pensamiento y de las actividades plásticas, tales como: la teología, la moral, la retórica, la astrología, las matemáticas, la geometría, la medicina, la arquitectura, la escultura, el grabado, la anatomía y las lenguas. Fue sin duda, un hombre universal, que se relacionó con algunos de los personajes más importantes de su época: en España, fue propuesto maestro del Príncipe Baltasar Carlos y, más tarde, fue protegido por los Duques de Béjar. Asimismo, en Italia, durante su estancia romana mantuvo relación primero, con el Papa Alejandro VII, quien le concedió importantes dignidades y, luego, con la discípula de Descartes, la singular Cristina de Suecia a quien retrató. Probablemente, abandonó Roma en 1665 y al año siguiente pasó al cenobio casinés, sin embargo aquel no fue, como hemos demostrado, su último viaje, ni su retiro definitivo. El benedictino, con 66 años, pasó por Trevi nel Lazio y, dos años más tarde, por la ciudad del Aquila, en donde creemos debió permanecer algún tiempo, pues allí compuso y fechó dos dibujos en los años 68 y 69.

$\mathrm{Su}$ condición de hombre inquieto, culto y universal, nos hace imaginarle atento a las corrientes pictóricas y artísticas en general, de la Italia de su tiempo. No obstante, como ya hemos apuntado, su pintura en Italia, por el momento, no refleja influencia alguna del arte italiano de la segunda mitad del siglo XVII y se mantiene en la misma línea estilística que desarrolló en España. La profundización sobre el por qué de este último aspecto, el estudio de su estancia en L'Aquila, la posible ejecución de más obras para las iglesias de otras poblaciones cercanas a Montecassino y la probable realización de grabados, como se intuye por las inscripciones de sus dibujos, son algunas de las incógnitas que nos proponemos despejar, en lo sucesivo, para esclarecer, con la mayor precisión posible, la historia del viaje a Italia de fray Juan Rizi, que ya empieza a perfilarse. 